\title{
STUDY ON THE FUNCTIONS OF COCHLER AND VESTIBURAL ORGAN OF THE DEAF
}

\author{
By \\ T. HOSHI \\ From the Dept. of the Special Education of Tokyo University of Education \\ (Director: Prof. K. Suhara, Instructor: K. Fujita)
}

Part 1: About the pure-tone audiometry of the deaf

180 deaf (3 21 yrs of age) were studied annually for three years with the audiometer $(1000 \mathrm{cps}$. max. power $125 \mathrm{db}$ ) and obtained the following results concerning the annual change of the type and the degree of the hearing loss and some characteristics of congenital and acquired deafness.

1. In $93 \%$ of cases contained the type of high-tone hearing loss and flat-type hearing loss. The majority of the average hearing loss was between 80 and $100 \mathrm{db}$. There were no remarkable difference between the hearing of right and left ear.

II. There were some progressive cases in the acquired deaf, especially in younger deaf children.

III. No difference was proved in the type of hearing loss between the congenital and the acquired deaf. The acquired deaf were invaded more severely than the congenital deaf.

IV. The similarities were presented in the audiograms of the brothers and sisters. However, the degree of their hearing loss were not the same.

V. The deafness, caused by infantile paralysis was more severe than those of caused by meningitis and encephalitis. There were many varieties in the type of audiograms of the deaf caused by labyrinthitis.

Part II. About the cupulometry of the deaf.

100 cases of the deaf (congenital 50, acquired 50) were studied to investigate their vestibular function by subliminal rotation test (cupulometry), and the results were compared with that of the Bárány test.

I. The positive reaction of nystagmus appeared in bigher percentage in the cupulometry than in the Bárány test. (cupulometry $86 \%$ vs Bárány test $75 \%$ )

II. The positive reaction of nystagmus appeared in the same degree between the congenital and the acquired deaf by the cupulometry, but they appeared unequally in the Bárány test.

III. There were more cases who had equally impaired vestibular function in the acquired deaf than in the congenital deaf. As congenital deaf, many cases had better reserved vestibular function than that of the cochlea.

IV. In $50 \%$ of the congenital deaf brothers and sisters, the cupulograms were proved the same type. Deaf brothers and sisters who had deaf parents presented the similar type of reaction, and showed no similarity among the deaf cousins.

V. The vestibular function was severely destroyed in the acquired deaf caused by meningitis, encephalitis, infantile paralysis, and less invaded in the cases which caused by intoxication of streptomycine, labyrinthitis and brain injury. 


\section{ろうの聴器機能に関する研究}

前編 Pure Tone Audiometry よりみた聴覚機能について

東京教育大学教育学部特殊教育学科生理研究室

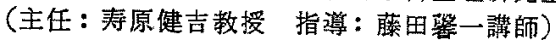

星融雄

目次

1 猪 諭

1 检查対象と方法

1. 被椮者

2. 検查場所

3. 検查期間

4. 湘定装膡

5. 測定方法

III検查成結

1. 聴力型について

2. 测定周波数衈力損失頻度分布について

3. 平均㯖力損失值について

4. 先天・後天別聴力像について

(1) 聴力型の頻度分布

(2) 平均聴損の頻度分布

N 戀括之考按

1. 聴力型について

2. 聴力損失頻度分布について

3. 聴力の経年変化について

4. 先天・後天別聴力倸の相違について

(1) 先天る5の聴力像

(2) 後天万弓の衈力像

$V$ 結鼠

\section{I. 緒 諭}

ろらの聴力を精細に検亘し、それに種々检討を加え、る 5発生の mechanism にまで及んだ業續 1)2 3)4756)738)は 数多く見受けられるが，な拶多くの未舠決の問題か䂝さ れている。殊に近時電気音響学の進步に伴い，特にろう 学校に扎いてはその力面の知識を導入し広く聴能訓練 (auditory training) t行つているが，彼等の居つ残存 聴力を有效に活かして, 口話法, その他の方法ととるに 交信手段 (method of communication) の向上を計万 らとしている。そと場合補聴器は重要な補助具となる が，その装用に当つては先ず聴力障害がいかなる状態に あるかを適切に把握しなければならない、また彼等の残
存聴力を保筧するためには，その実態は明らがされな け机ばならない、私はこのよらな見地からろらの聴覚に 関する破究の基砝として特に設計されたるら用 Audiometer によつて 数年来純音聴力測定を行つてきたが、る 年閒 3 回に啮万聴力検查の結果種々の成績を得たのでこ こに報告する次第である。

\section{II. 検查対象と方法}

1. 被 検 者

榆査の対象は東京教育大学教育学部附属了与学校在学 生180名（3才〜21才）であり，その一覧表を第1表に 示す，更にこれら被検者中より問診及び全身並びに局所 所見から比较的正確に失管原因知り得た先天及び媵天： らら各50名を抽出して詳細な检討を加えた。

第 1 表 被検者一覧

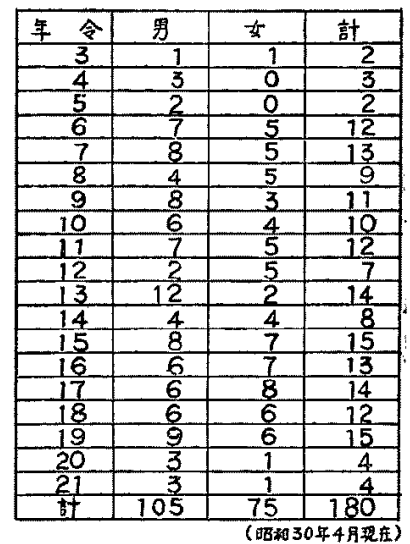

2. 梌查場所

検查の場所住東京教育大学国付台分校生理研究室内に: 設置された防音室（遮音量 $60 \mathrm{db}$ ）。

3. 検查期間

昭和 28 年 4 月より昭和 30 年 8 月までの間に年 1 回宛: 次のようにして純音気觎聴力測定を行つた。

第 1 回：昭和 28 年 4 月～同年 7 月

第 2 回：炤和 29 年 2 月〜同年:5月 
第 3 回：昭和 30 年 4 月 同年 5 月

4. 測定溹

第 1 回測定では小林理研製作所製 Rion 1002 型 (Bo-oster 付, 最大出力 500 4000 cps 間 $125 \mathrm{db}$ ) Audiometer, 第 2, 3 回の測定では 同製作所製 Rion 1004 A 型 Audiometer 使用した。

これらの Audiometer はいずれるらら学校用として '特に設計されたもので, Rion 1004 A 型 Audiometer はJIS 規格に合致するものであり， receiver は出力が 大であるために trumpet speaker unit を使用した．

第 2 表に示す如く気尊の最大出力はほら゙最大可聴音圧 に一致している.

第 2 表 Rion $1004 \mathrm{~A}$ 型 Audiometer の最大出力

\begin{tabular}{|c|c|c|c|c|c|c|c|c|c|}
\hline $\begin{array}{l}\text { 周波媱 } \\
\mathrm{kCPS}\end{array}$ & 125 & .25 & .5 & 1. & 2. & 3. & 4. & 6. & 8. \\
\hline $\begin{array}{c}\text { 最大出力 } \\
\mathrm{db}\end{array}$ & 95 & 105 & 120 & 125 & 125 & 125 & 125 & 105 & 105 \\
\hline
\end{tabular}

5. 测定方法

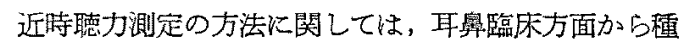
種検討が加えられ現在臨床的には統一されているか゚ 9 ， 本実騟はそれ以前に始められかつ被険者が高度難聴又は ろらで亦るといら特別な条件を考慮に入れて3回上も次 の上らな方法により湘定を行つた。

な和測定の実施は被娭者のろう火伴う言語障害のため 殊飞年少者については極めて困難な場合が多く、か、る ものについては測定值が安定する迄日を换えて测定を絽 返した。

测定は先ず被検者をべットに仰呞せしめ，receiverを 固定台に載せて耳部に固定し，測定音が聴光ている間は 被検者の手を開くことで合図させた，湘定周波数の順序 は $1000 \mathrm{cps}$ 上り始め次第に下げて $125 \mathrm{cps}$ に至り, 再 び $1000 \mathrm{cps}$ に底し次で $8000 \mathrm{cps}$ まで順次上げて測定し 最後に $1000 \mathrm{cps}$ を測定して完了した．各周波数に护け る聴力損失值の決定は $5 \mathrm{db}$ step で断続下降法及び上昇 法を繰返し、下降法での値を探つた。

以上の方法で 3 回測定を繰返しその際の最䪹値をるつ て各周波数に猢る聴力損失值とし Audiogram を作 成した。な測定に当つて良聴耳に対して masking は 行わなかつた。 また各年度毎に，测定終了後健用した Audiometer の較正を行い，各周波数毎に変動のあつ た部分では測定值を補正した。

\section{III. 検 查成樍}

1. 聴力型について

得られた Audiogram については，その聴力型をそ れそれ次のような基準に從つて分類した。即ち高音障害 型, 水平型, 低音障宫型, 凹型, 凸型, 聴島及び無反応の 6 型に大別し，高咅障害型及び低音障害型は $250 \mathrm{cps}$ と $4000 \mathrm{cps}$ との間に $20 \mathrm{db}$ 以上の差異を示するの, 水平型 は各測定周没数の変動が $20 \mathrm{db}$ 以下に止るもの, 田型, 凸型はこの間でそれぞれ $20 \mathrm{db}$ 以上の低下及び上界を 示すもの, 聴島及び無反応は 3 種以下の測定周波数で僅 が最大出力音圧の近辺で反応を示すか全く反応を示さ ないものとした。

第 1 図 聴力型に上る分類

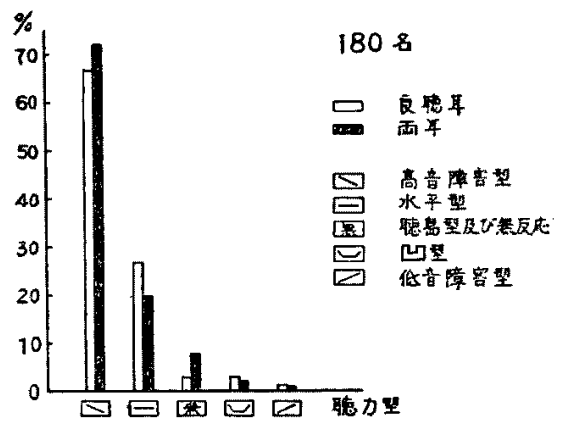

第1図は上記の方法に徒つて分類した180名の各聴 力型の頻度を示したものである.縦軸は頻度を百分率 で示し，橫軸炕は各聴力型を並べた。即号高暗障害型 を目，水平型を 二，低音障害型を 一，凹型を

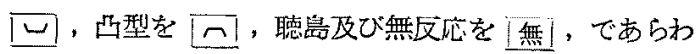
してある・黒柱は 180 名の両側 360 耳の聴力型分布であ

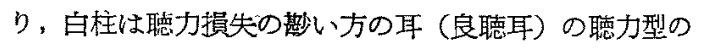
分布を示す

左右 360 側の德力型の分布をみると頻度の最高恃高音 障害型で $72 \%$ を占め，次に水平型が多く $19 \%$ で聴島び 無反応，凹型，低音障害型は僅かな頻度を示している。 良聴耳 180 耳についてみると両耳の分布に比較して高音 障害型が $67 \%$ に減じ，これに反して水平型が $27 \%$ に增 加している。

第 2 図は同一被険者の両耳聴力型の頻度分布を示す ものである. 即ら横軸恃両耳の聴力型の 組合をを同一 口内に記入して頻度順に配列し，縦軸にはとの頻度を 百分率で示した。これによれば両側ともに高音障害型を 
示すむのが大多数を占めて60\%を越克，次で一側高音 障害型他側水平型のものが $17 \%$ あり，両側とも水平型 を示するのが7\%を占めている.

第 2 图 両耳聴力型の纱度分布

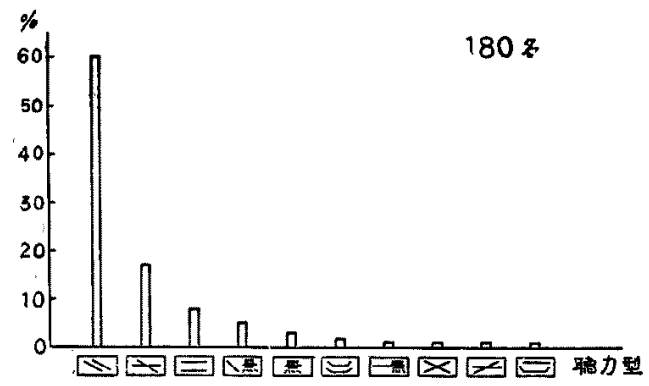

2. 測定周波数毎の聴力損失頻股分布について 第 3 図は 9 種類の測定周波数に拉ける聴力損失の頻度 （\%）分布を示す．横軸は聴力損失を示し聴力損失 $25 \mathrm{db}$ より $1004 \mathrm{~A}$ 型 Audiometer の最大出力 $125 \mathrm{db}$ に涉 り、反応のないるのつ頻度を右端に示した．縦軸は各测 定周波数毎に聴力損失の頻度分布を百分率で示した。

\section{第 3 図各周㳊数の聴力損失頻度分布}

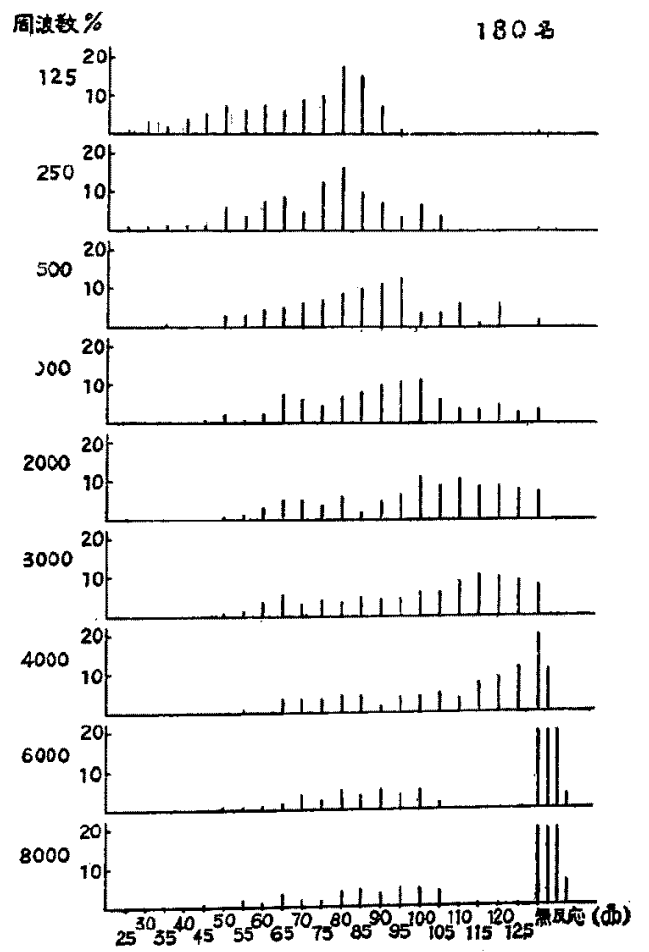

測定周波数が高くなるに従つて聴力損失の大なるるの が多く，250cps では $80 \mathrm{db}$ の聴力損失のひのが $17.4 \%$ で最高を示し，次で $85 \mathrm{db} て ゙ 14.6 \%$ を占めている. 他 は順次聴力損失の軽度な子の克之減少し，最小聴力損失 $25 \mathrm{db}$ から最大 $95 \mathrm{db}$ に及九ている。

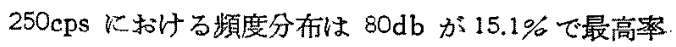
を占め，これを頂として $25 \mathrm{db}$ より $105 \mathrm{db}$ までの間

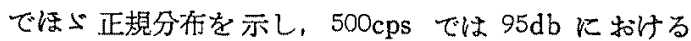
13.4\%を最高として $35 \mathrm{db}$ より $120 \mathrm{db}$ までの間には心 正规分布し，1000cps では $100 \mathrm{db}$ に持ける12.3\%を 最高として $45 \mathrm{db}$ より $125 \mathrm{db}$ の間汇よ゙正規分布し， 2000cps では $100 \mathrm{db}$ 亿おいて $11.8 \%$ が最高であるが 50 $\mathrm{db}$ 上り $125 \mathrm{db}$ までの間に少数が分布し 正規分布を示: さない, $3000 \mathrm{cps}, 4000 \mathrm{cps}, 6000 \mathrm{cps}, 8000 \mathrm{cps}$ 等活い

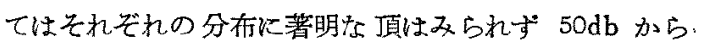
Audiometor $の$ 最大出力音仕の 間に少数例分布するに 過ぎない。

Audiometer の最大出力音圧でるな打反応しないるの は周波数が高くなるに従つて著明に增加し，その頻度 は $125 \mathrm{cps}$ で $0.6 \%$ ，250cps で $0.6 \% ， 500 \mathrm{cps} て ゙ 2.2 \%$ ， $1000 \mathrm{cps}$ で $3.4 \%$, 2000cps で 7.3\%, 3000 cps で $8.4 \%$, $4000 \mathrm{cps}$ で $31.4 \%, 6000 \mathrm{cps}$ で $64.4 \%$, $8000 \mathrm{cps}$ で 66.6. \%となつている.

3. 非均悪力損失值化ついて

平均聴力損失値（以下平均恶損と記す） は $500 \mathrm{cps,}$ $1000 \mathrm{cps}, 2000 \mathrm{cps}$ に㧍ける 3 䏇力損失值の平均值であ る. 3 周波数の中でいずかが最大出力 $125 \mathrm{db}$ です無 反応の場合はその周波数の䏇力損失を $125 \mathrm{db}$ として計 算した，第 4 図は被㭘者 180 名の平均聴損の頻度分布図 である. 平均聴損の程度により9群に分けて横軸とし， 綎䡩はそれぞれの群の頻度を百分率で示した，白柱は良。

第 4 図 平均聴力損失值の顿度分标

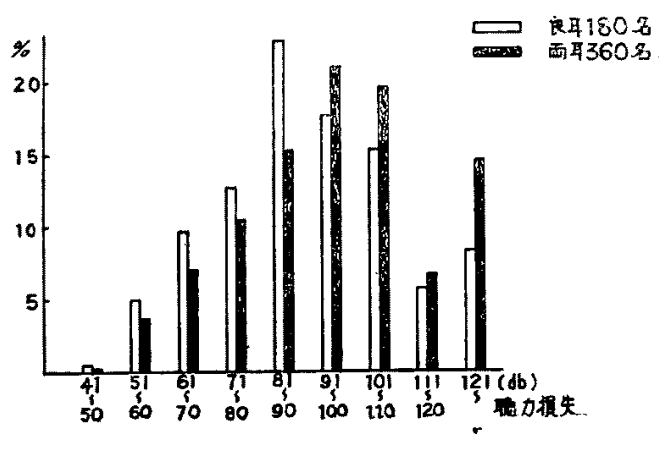


聴耳の，黒柱は両耳の平均聴損の頻度をあらわす．両耳 360 耳の平均㯖損分布では “91 100” db 群が最高 $21.3 \%$ を占め, 次で “ $101 \sim 110 ” \mathrm{db}$ の $19.6 \%, “ 81 \sim$ 90 ” db の 15.6\%，“121〜” db に 14.8\% の順に分布し

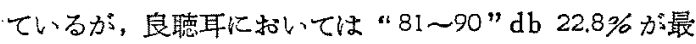
高で順㳄 “91〜100” db の 17.8\%, “101 110” db の $15,6 \% ， “ 121 \sim ” \mathrm{db}$ の $8.3 \%$ K減してて扣り，分布曲線 快聴力損失の䟞い方に移動している。

4. 先天・後天叫聴力像について

(1) 聴力型の頻度分布

第 5 図は先天・後天各 50 名について良聴耳の それぞ 机の聴力型の頻度分布を示す。黑柱は先天, 白柱は後天 であるが先天・後天とむに高音障害型が圧倒的多数を占 めそれぞれ 62\% 及び 64\%に達し，次に水平型が多く， 先天 $32 \%$, 後天 $24 \%$ となつている.

第 5 図 先天・後天別㯖力型の頻度分布

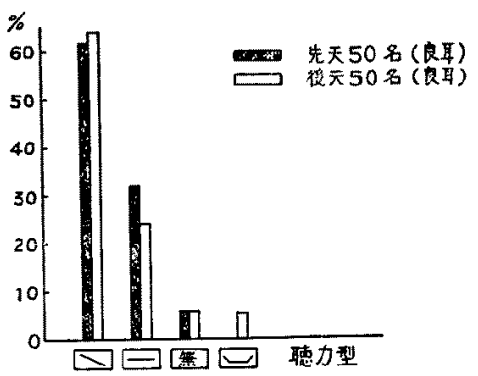

（2）平均聴損の頻度分布

先天・後天各50名，それぞれの耐側 100 耳について 平均聴損の頻度分布を第 6 図に示した，即ら先天で “101〜110” db に最高30\%を示しているが，後天で 俚 15\% に過きない，又後天では“121〜” db 最高 $26 \%$ 定上るが，先天では僅か７％に過ぎない，次に“81〜

第 6 図 先天・後天别平均聴力損失值の頻度分饰

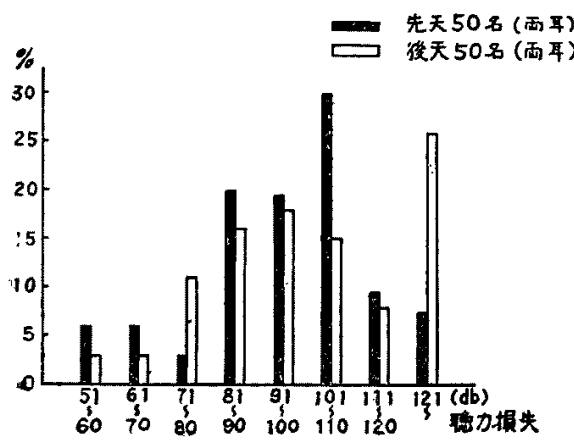

$90 ” \mathrm{db}$ で先天は20\%，後天は16\%に達し，“91〜 $100 ” \mathrm{db}$ では先天及び後天がそれぞれ19\%，18\%とほ 活同数を占めている. 以下“71〜80” db, “111 120” $\mathrm{db}$, " 61 70" db, “51 60" db の順に激次減少を示し ている.

\section{IV. 總括之考揬}

ろうの聴力関する内外の文献は数多く又られる.古 (《 Bezold 1), Brock 2), Hasslauer 3), Denker ${ }^{10)}$,

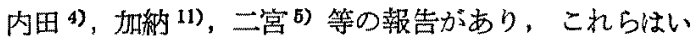
ずれる Bezold-Edelman 氏連続音叉叉は Hartmann 氏連続音叉を用いて聴力㭘查を行い，失官原因別に，又 は先天・後天別に残聴の有無，聴力型等を検討したもの である. 近時 Audiometer による聴力検查成績も加藤 12), 高橋 ${ }^{6}$, 高橋》等によつて 報告せられ, 叉これと 前庭機能検查成績，受聴昽瞭度との 関保》等について も散見される。併し大部分の報告では最大出力がたが゙ か $90 \mathrm{db}$ 以内に止り，上り高度な聴力障害を有寸る多 くのろうについてはその德力の実態を確実に知ること は不可能であつた：私は幸いに前記ろう学校用として作 㢣された Audiometer によつて测定することができ，

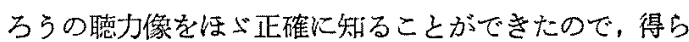
れた結果について次化記すような考察を加光た，万う学 校用として作製された Audiometer の最大出力は第2 表に示寸如く，ほ心゙最大可覚凰 (threshold of feeling) に一致している。このように音圷が大である場合には， 当然音感覚以外飞振動感覚们対して反応するという危除 性を考慮に入れなければならないが，このことは，骨導 聴力測定の場合活ど顕著とは思われず，䏯力損失値に個 人差が認わられず且同一被検者についても左右差がある ことょり，本検查に打いては無視された．年少者の聴力 測定は play audiometry あるいは他覚的 audiometry 等の方法で行らことが望ましいが，3回の測定結果から 判断して忍耐強く行えばかなり正確に測定できることか゚ 知られた。

1. 聴力型沉つて

聴力型を6 稬類に分頪した Bezold1)の方法に従つて 检討された報告は望だ多い，併しその成績には相当の差 異が欢られる。

第1図は現在広く用いられている聴力型の分類に従つ て，被検者 180 名の聴力型の 頻度を示したものである が，これによると高音障害型が圧微的に多く，次儿多い 水平型と合せると $94 \%$ を占めて括り，且水平型の大部 分も文高音障害型に準ずるような㯖力型（晫度高音障害 
型つを示し，聴島及び無反応は㑑が $5 \%$ 前後に 過ぎ ず, 聴力の全廃者は䟞いとい上得る、低湆障害型は被検 者 180 名 360 耳中僅か 2 耳にみられたに過ぎない，以上 より高度の感音難㯖を有するもの〉㢺力型は殆んど高 音障害型であることが知れる. 更に良聴耳と両耳の分布 比較すると，良聴耳では車耳より水平型が 7\% 多く， 逆に高音障害型が7\%減している。このことは璃力障書 の高度なものが更に增悪するに從つて长平型より高音障 管，聴島及び無反心へ之聴力型の愁行がみられること を示すののである。

第 2 図の同一被検者について両耳の聴力型の頻度分布 をみると，両侧同型のものが最も多く75\%を占め，こ

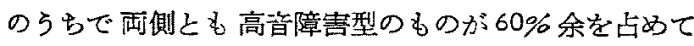
いる．聴島及び無反応悝が $3 \%$ で，先人の報告 ${ }^{122}$

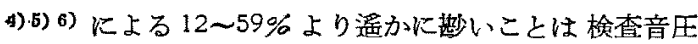
に差異があるのたから当然のことである．又片側完全る うについて子同様のことが云える。

以上のことから，病的侵笨が内耳，㬝神経を侵す場合

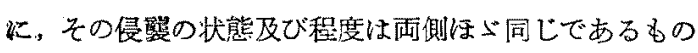
が多いと考党られる。

2. 聰力損失頻度分布について

各周没数別に聴力椇失の頻度分有図（第 3 図）をみる と，いずれの周没数でる頻度の最高率を占める位置は $80 \mathrm{db}$ 以上のところ，あるいは最大音任に近いところに

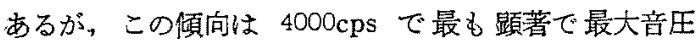
$125 \mathrm{db}$ K一致し，6000 cps. $8000 \mathrm{cps}$ ではこのような傾

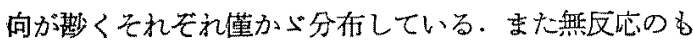
のは周波数を增すに従つて增加するが，4000 cps，6000 cps で急激に增加し $6000 \mathrm{cps}$ 以上では被椎者中の過半 数が反広を示さない，即ら第3表ては上段の測定周波数 に対し，各周波数每の最高頻度及びそれに相当する音圧 を中段に揭げ，下段には無反応の頻度を百分察で示し to.

第 $\mathbf{3}$ 表 各周汶数に招ける最高頻度，乙の音圧 及び無反応者百分率

\begin{tabular}{|c|c|c|c|c|c|c|c|c|c|}
\hline $\begin{array}{c}\text { 周彼数 } \\
\text { CPS }\end{array}$ & .125 & 250 & .5 & 1. & 2. & 3. & 4. & 6. & 8. \\
\hline$\underset{d b}{\text { 诗度音压 }}$ & 80 & 80 & 95 & 100 & 100 & 115 & 125 & 90 & 85 \\
\hline 最高教㭟 & $(174)$ & (15.) & $(43,4)$ & $(123)$ & (118) & (118) & (123) & $(50)$ & (45) \\
\hline 喜反応 & 0.6 & 0,6 & $22 \mid$ & 3.4 & 7.3 & 8.4 & 314 & 64 & 666 \\
\hline
\end{tabular}

以上の結果は潩力型において高音障害型が大多数を占
めていること〉相侯つて，ろうの残聴は低音部にあり， 聴島型においても高音障害型飞準ずる畗力像を呈し，中 はり但音部に残聴がある。このような但音部残聴につい ては振動感覚に関する詳絉な研究と相俟つて正碓な判 断が下されなければならない，又感音難聪の初期症状と

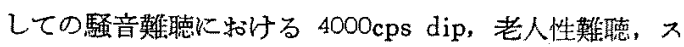
トマイ難聴の潜在性高音部陡書とろうの聴力像とに類似 する点がみられることは興眣深い。

平均聴摃分布については第6図に示寺如く良聴耳“81 〜90” db，両耳 “91〜100” dbをそれぞれ最高频度之 してほ心゙正嫢分布し，“121〜”dbでばや」增加し且良 聴耳と両耳とでは6\%余の垟が文られる。.Bezold 1), 二

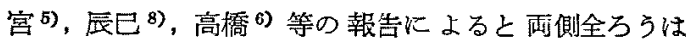
そ机旮れ 44.9\%，11.4\%，19.0\%，59\%とあるが，これ は“71〜80” db 万至は “81〜90” db 以上の聴力損失 を有するものすべてを含んだすのでこっにも検查音压 の差異による成結の違いがみられる。

同一被捡者炕和ける在右聴力の差暴（第7図）はあま

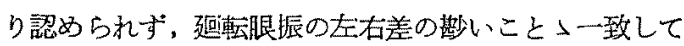
いる．即ち左右平均聴損が同程度であるものが全体の路 半数を占め, 測定誤差を $\pm 5 \mathrm{db}$ とて平均檩損の差 $10 \mathrm{db}$ 以内に止るものを含めると約 $65 \%$ に上る. 又最 高 $50 \mathrm{db}$ まで左右差が認めら和るすのが僅かづ分布 しているが，これらについては更に masking を考虑に 入れて検势しなければならない，以上からろらの多くは 病的侵留を耐耳同程度にらけていることが推定される。

第7四两耳㯖力盖

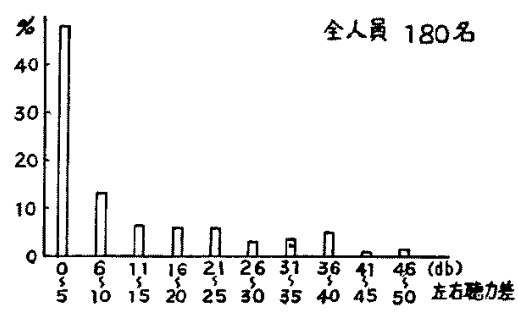

3. 聴力の経年変化について

昭和 28 年か 530 年までの 2 力年を経遗する間に同一 被検者の㱬力がどの上うに变動するが観察した。，第 8 図は聴力差の頻度分布を示卞すのであるが昭和 30 年度 の平均聴損から 28 年度の平均聴椇を差し引いた第 1 群 (実線)と，29年度のと机を差し引いた第1群 (点線) とを併記したすのである。即ら被検者各々の 2 年間及び 1 年間の嘼力変動の頻度分布を示子. 横軸 “ $-5 \sim 5$ " db 
上の点線の高さは聴力の変動が $-5 \mathrm{db}$ から+5db 以 内のむの頻度を示すこの線より向つて右に偏すれば （正の值で示す）それだけ聴力が低下したことを意味し， これから左に偏すれば（負の值で示す）それだけ聴力が 良くなつたことを意味している。

第 8 図 経年聴力変動の頻度分布

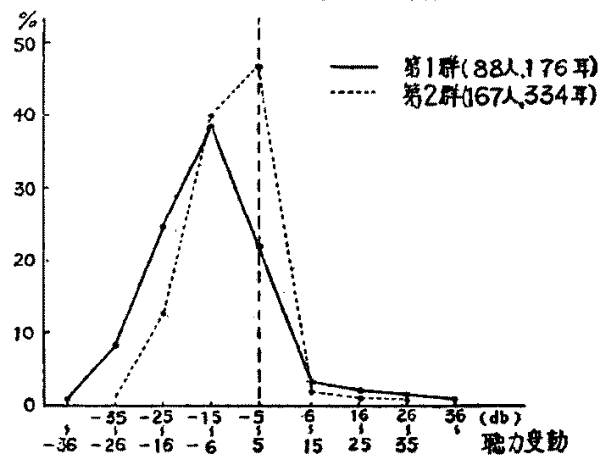

第 [群（88 人，176耳）の頻度分死（実綜）は，第 II 群（167人、334耳）の頻度分布 (点線) 飞比して分布の 頂が苃に偏し，見掛上聴力が良くなつたようにみえる が、これは28年度に用いた Audiometer の Odb が 正常聴力者の可聴間值を以て決定したものであり，29， 30 年度に使用した Audiometer が JIS 規格によつて Odb を規定したものであるため，この間両者で約 $10 \mathrm{db}$

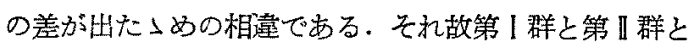
の閣には著明な差異はなく，ほ今゙同様の頻度分布を示 し，聴力の変動はあまり認められないと考学られる。乙 かし第】群之第【群の分布の頂を同一軸上に置き換えて 分布をみると，第 1 群で右作偏するものがや小多い：こ のことから 1 年間で上りも2年間で聴力の低下している ものつあることがうかがえる。

4. 先天・後天別聴力像の相違について

先天・後天別の聴力型の頻度分布（第 5 図）では差異 が認められないが，このことは從来の報告ともよく一致 する.

次比先天・後天別の聴力損失の頻度分布図（第6図） では，先天上後天でそれぞれ頻度の頂を異にし，先天で は “101〜110” dbに，後天では “121〜”db のとこ ろにあり，更に聴力但下の勘いるのが先天に叔いて後天 上り多く分布している. 㕛後記の如く迴転性腿振の梌查 成綘でも同样の傾向を認めている，更に機能低下又は廃 絶のものが後天に多く，交献上先天上りも後天に完全ろ

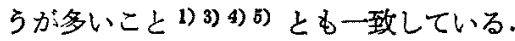

第9 図恓天・後天別の両側耳聴力差の頻度分布図で あり，黒柱は先天，白柱は後天を示す. 左右耳の聴力の 差の卙いものが後天で多く (9\%)，先天で左右耳の羛の あるものが多いことは，少数例であるので速断は危険で あるが，後天ろうでは病的侵䡔を同時に同程度に受ける ことが多いと考党られる。

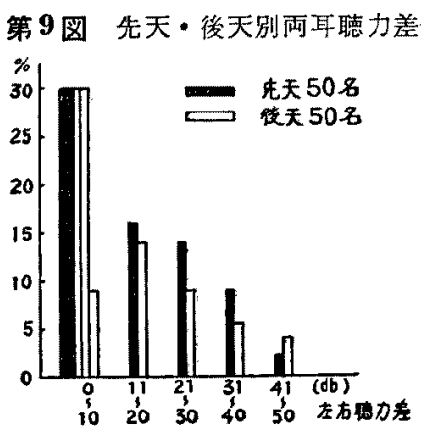

第10困は先天及び 後天ろらに打子る 2 年間の聴力の 変動を示す 即方同一被梌者の 30 年度の平均聴損から 28 年度のそれを差引いたものを横軸て、頻度 (\%) を縱

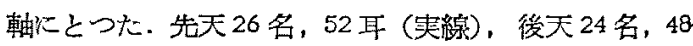
耳 (点線) の曲線を比較すると, 先天に比へて後天では 頻度の最高が右方に腐している、これは被検者 50 名中 先天では聴力の增悪するものが極めて眇いが，後天ては 著しく多いことを物語るものである。

第 10 図 先天・後天別経年德力变動の頻度分布

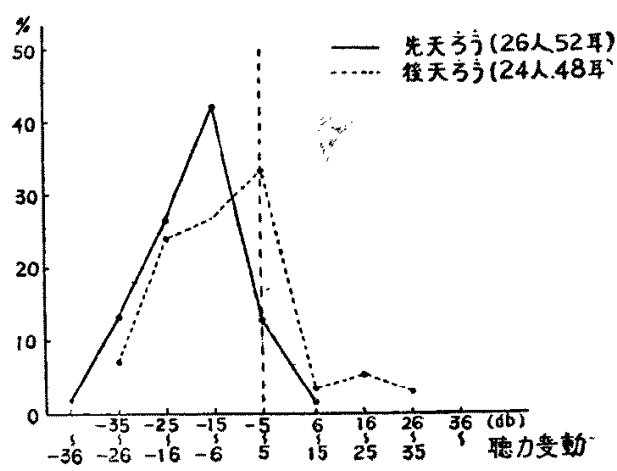

更に第11図に扎いては㙏力の增覀が認められる後天に

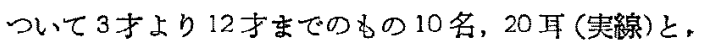
13 才ょり 21 才までのもの 14 名, 28 耳 (点腺)の 2 年 間における㯖力の変動を示した。これによると若年者の 分布の最高が右に偏しており, 明らかに高年者より若年 者て聼力の增悪をきたするのが多いことが知れる。 
第 11 後天万弓の程年聴力变㽖の頿度分布

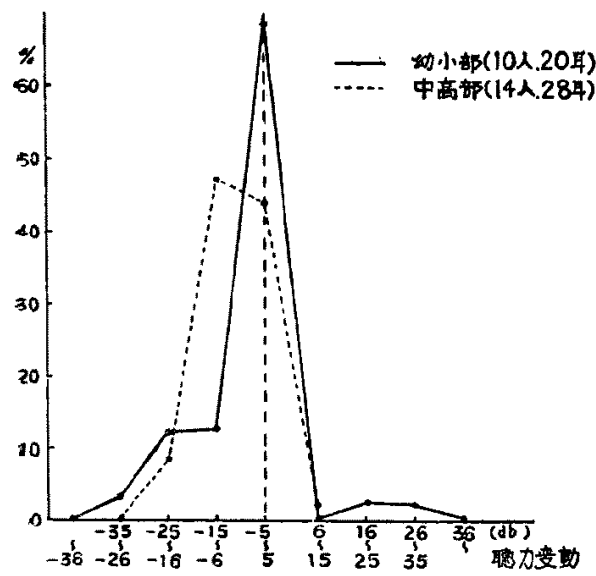

以上のことより聴力の增悪は先天より後天に多くみら れ，更に後天では若年者に多いことを知つた。この理由 として生後のある時期に蛙いて重篤な疾患を経過し，之 のために聴覚機能の低下をきたしたが，就学後間もない (3才で入学する) 時期では聴器の变性は治湶あるいは 固定壮ずな拓進行中のbのが多いと考えられる。から ら学校ではこの時期に auditory training を課し, 補 聴器萦用䚴練を行らなど，大きな音刺㦸に暴射されるこ とが多く、これがろう奣には意外に強く感受されること は DL test により明らかにされたことであつて，この 音響外傷が不安定な内耳，聴神経を犯すか子知孔ない。 これに反し高年者に㧧いては一般教課が多く auditory training 行はない。

近時万ら教骨は幼稚学級を設けるなどますます纱少時 上り開始する傾向にあるから, 聴力保存のための措置も 又同時に行わねばならないことを痛感する。

(1) 先天万5の㯖力像

第 12 図には，ろ5兄弟の Audiogram を同一図中に 記した. 即ち先天 50 名中 32 名は兄弟方るいは徒兄弟で あつて，その内訳汉生児 1 組（第 12 図，8），3人兄弟 が3組（第12図，1〜3)，従兄弟3名1組（第12 图， 4), 兄弟 2 名9組（第 12図，5７，9１4）である。図 中実線，点線等それぞれ綵種を換えて各被检者の Au* diogram を示している.

一泗坐双生咱の聴力像恮く類似し左右差なく, 前庭 機能（偻篇第 8 図 8 参贸）あ同様の低下を示し左右差は 勘い，兄弟同志の㯖力型は任心同型であり，かつ聴力損 失では殆んと同程度のすのは第 12 図 3,5,7,9,11,13,14 の7症例に，多少の差のあるbのは第 12 図 1,2，6，10，

$11-127$
第I2図 弓亏兄弟の Audiogram
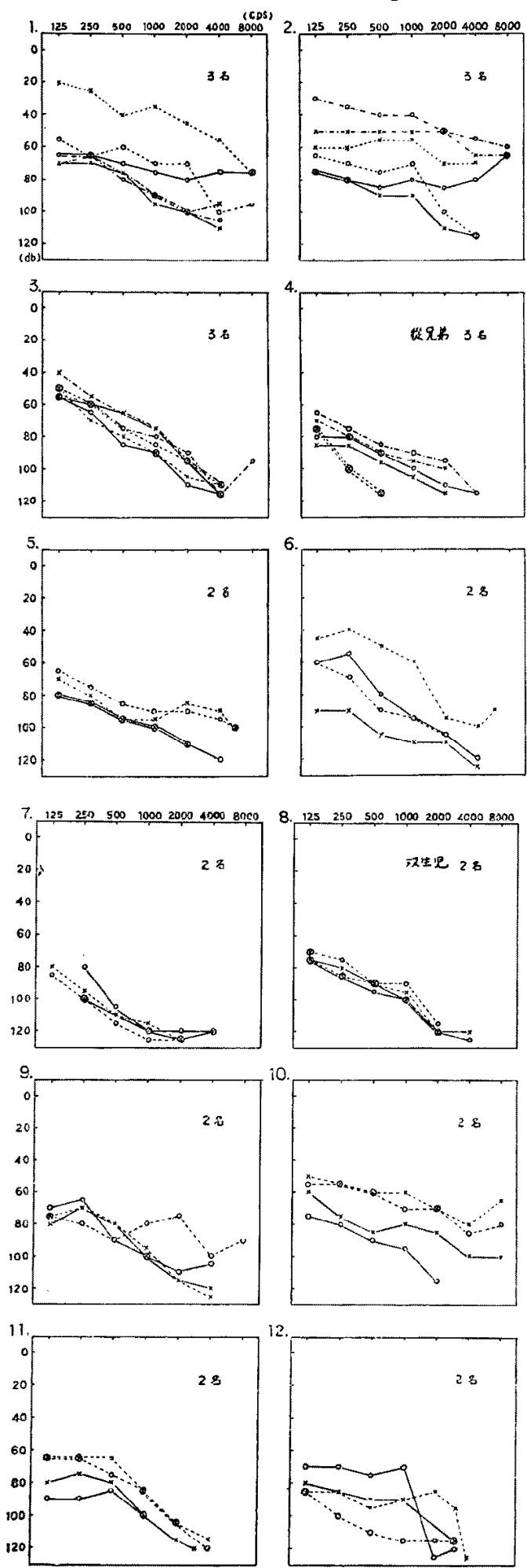


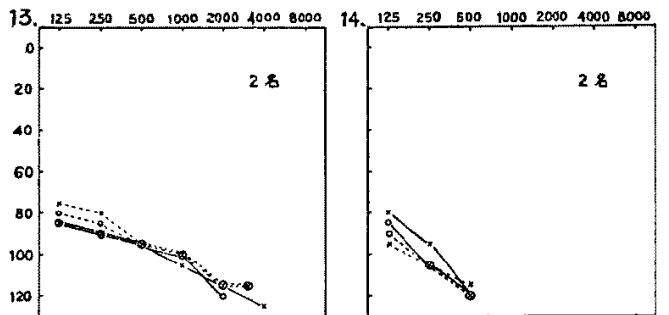

12 の 症例である。これを Cuplogram(後篇第8图参 照) と比較すると，第 7 図中聴力損失同程度のもの 7 症例 中 7t除全症例に拈いて Cupulogram の反応様式が 同じであり，聴力損失に差のみられた 5 症例に扎いては Cupulogram にも又同样差が認められている，第12図 7 の症例のみ台兄弟 2 人の德加像加近似しているにもか かからず前庭器の反应様式が異つていた。これにより不 弟の 聼覚及び 前庭機能の反応様式は類似するものがあ ることが知られる，第 12 図4の母親同志が姉妹である 従兄弟3名の Audiogram は同型で, 共に高度の障害 を有するが，Cupulogram の 反応様式は 3 名とも相巽 り，正常值より算までに造つている.

第 13 图失官原因別にみた後天ろらの Audiogram
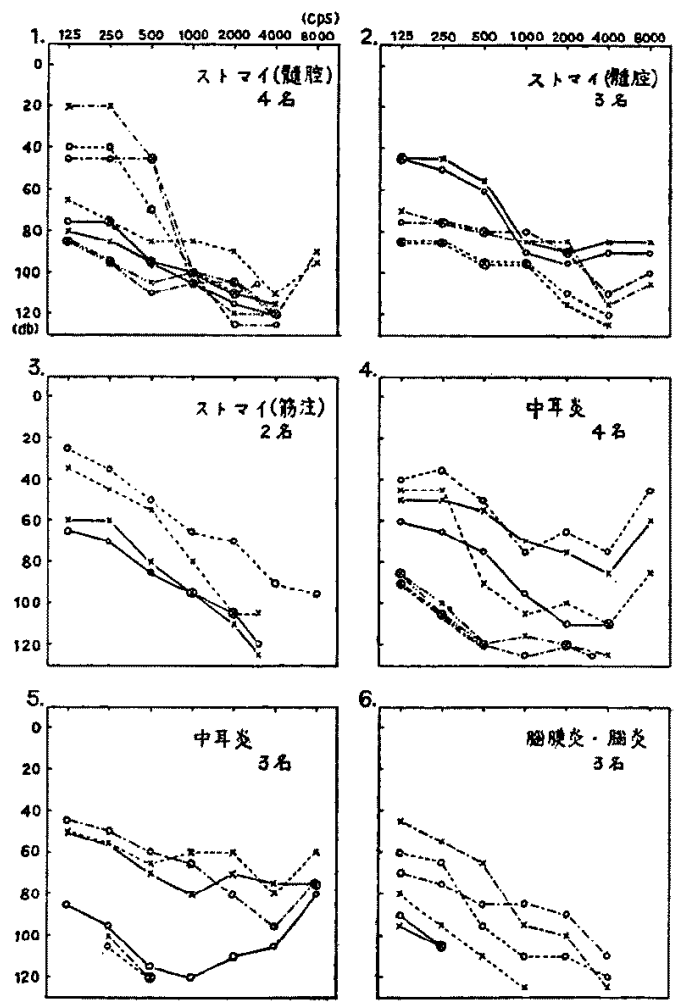
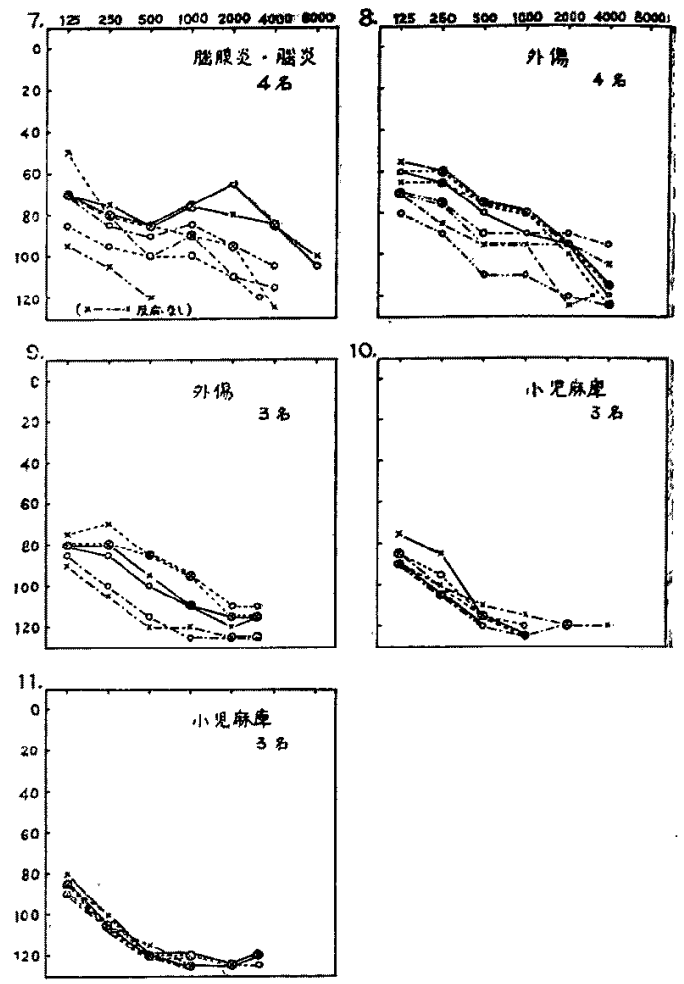

(2) 後天ろうの聴力像

第13 园は後天万ら50名を後記前庭篇亡同じく原因敖 KStreptomycin 9 例 $(1 \sim 3)$, 中耳炎 7 例 $(4 \sim 5)$, 脳 膜炎及び畄炎 7 例 $(6 \sim 7)$, 頭部外稘 7例 (8－9)，小兄 麻痺6例 $(10 \sim 11)$ に分類した Audiogram である.

Streptomycinによるらうの中，铕腔内に注入した1。 2 に示す7名の Audiogram はいずれも定型的な高音障 害型で特に高音部での低下が著明なるのが多いが，低音 部では比較的残聴のあるものもみられる (14耳中 5 耳). これは Streptomycin の量,あるいは体質等に関俰する 13）すのと思われる. 又 Cupulogram（後篇第 9 図 1，2" 参职はいずれも焦下を示しその程度はほら゙残聴と亚行 するもの多く, Streptomycin は前庭器をも犯すことが らかがえる. 3 K示す筋注の2 例では聴力前庭機能す 低下の程度は比較的軽い。

中耳炎による失官? 例についての Audiogram 4, 5 , では Cupulogram（後篇第9図 4,5参照）之同様聴力 低下は軽度のるのから高度のるのまでまちまらであつ $\tau$, 煨力の低下と前庭機能の低下とは並行せず，聴力型

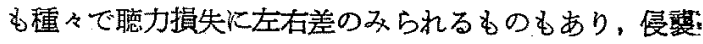
の様式がまらまらであることが知られる。 
6,7は脳膜炎及び脳炎炕よるろう7 例の Audiogram である. 全例において高音部に高度の聴力低下を示し， Cupulogram（後篇9図 6,7参照）む高度に低下してい るののから全廃するすのまであり，聴力低下と並行して 高度の前庭機能の低下を示している。

8,9 K示す頭部外傷の7 例ては Streptomycin, 脳膜炎 によるろらとは異り，高度の聴力障害を有するにもか わらず，その Cupulogram（後篇第9図 8，9参昭）は 正常值を示するのから僅かな反応を示するのまであつ て, 聴喾器を高度に破壊する程度の外稘が前庭器に及ん でもなお前庭器の方が外力に対して抵抗が強いといらこ とを物語つている。

10,11 は小児麻猈によるもの6 例の Audiogram を 示す. 前記諸疾患によるううに比へてて聴力も前庭機能む 最む高度汇障害されており，本実験では全例が機能廃絶 飞近い，小児麻疩による侵警の激しさが知られる。

\section{V. 結 諭}

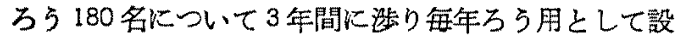
計された Audiometer によつて純音聴力測定を行い， その聴力像, 聴力の変動等について検討し, 百に被検者 中より先天・後天各 50 名を抽出しこれ等について璉々 検討を加党た結果，以下のような結諰を得た。

1. 㯖力型恃高音障害型が最多多く，次の水平型とで 大部分を占め，低音障害型及び全欠撌は極めて卙い，左
右耳の聴力型は同型のものが過半数を占める.

平均聴力損失は $80 \mathrm{db}$ 乃至 $100 \mathrm{db}$ のものが最も多く， 左右差は顥著でない。

2. 年 1 回づ\3 年に及ぶ聴力検查の結果では若干例 に聴力の低下が進行しているものがありこれは後天る うの中殊に若年者にみられる現象で内耳，聴神経の変性 があだ固定していないためと考えられる。

3. 先天と後天では聴力型以差異はなく，聴力損失の 高度なものは後天に多い. 左右耳の聴力損失に差のある 6のは，先天より後天に僅かながら多く認められる.

4. 万弓兄弟同志の 聴力型はほ心同型であり，㯖力損 失は約半数が等しく，他の半数は異つている。これは Cupulogram の反応様式と一致している.

5. 後天万弓失官原因別 Audiogram と後篇の Cupulogram とを比较検討すると，两者とも機能の荒廃の 最も激しいものは小胃麻㾇に上るむのである．脳膜炎及 び脳资に执いてる聴賞, 前庭器の機能の低下は著明であ る. Streptomycin の場合では著明な高音障害型を呈す るものが多く，聴覚，前庭両者の機能低下を認めるが， 薬剂の使用方法，量あるいは体質等によつて障害の程度 に差異が認められる，中耳炎及び外傷の内耳への侵襲様 式は雷々で聴力低下の程度に較へてて前庭機能の残存する

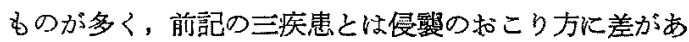
るものと思わ礼る。

\section{後篇 Cupulometry よりみた前庭平衡機能について}

\section{目次}

I 緒 諭

I检查対象と方法

1. 被梌者

2. 検查場所

3. 検查期間

4. 刺戟方法

II 検查成蹟

1. 各種趣転速度に和ける眼振持続時間の頻度の 分布

(1) Bárány 法によるもの（自由選択による被検 者群の価檤検討）

（2）閏值下加速度趈転刺䧧化上るもの

2, 先天・後天別の眼振持続時間の頻倿分布

N 䌊括之考按
1. 各種逜枟速度における眼振持続時間の頻度分布

2. 先天・後天別哏振持続時間の頻度分布

3. Bárány 法陰性で闒值下刺戟法陽性のものに対 する検討

4. 闒値下刺戟法による眼振持続時間と聴力との 関倸

5. 先天・後天別 Cupulogram の相違について

(1) 先天万弓の Cupulogram

(2) 後天万5の Cupulogram

$V$ 結 論

女献

\section{I. 緒 論}

ろうの前庭平衡譏能を迴転性後眼球振湯を中心として 誳べたものには, Strehl 4), Bruck 5), Bezold 1), Hasslauer ${ }^{3)}$, Denker ${ }^{10)}$ ，Brock 2) 等の報告がある。本邦化 


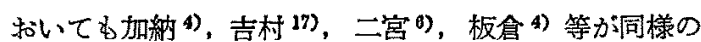
検查を行つている。しかしこれら諸家の行つた実験的前 庭機能検查法はいずれる Bárány 法 ${ }^{18)}$ (20 秒 10 延転 の等速度迴転刺㦸法）を基磷としている。しかるにこの 方法は最近北欧を中心とする諸学者により厳しい批判か゚ 加えられつ」ある。

すなわち Bárány 法では，（1）迴転速度が適刺㦸の

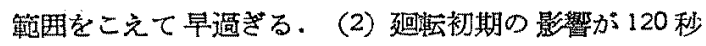
の長い間持続するため 廻転停止後の 反応に及ふ心、（3） 20 秒といら極めて短い時間の間㑑反する二方淌の迴 転刺㦸が半規管に加えられるために観察すべき眼振は単 純な前庭器の反沁とは考光難い19)。とされ，この上う な钼点から 1948 年以来 Van Egmond ${ }^{19)}$, Fischer ${ }^{20)}$, Hallpike ${ }^{21)}$ 等によつて種々の刺㦸方法が研究され，それ 飞伴つて精密な迴転装置が考按されている。これらの中 で Aschan 22) 等の提唱する閾値下加速度廻転刺战 (Subliminal acceleration) による後眼振 (after nystagmus）上後感覚 (after sensation) を観祭する方法は, 廻転感も眼振も起らない程度の加速度刺战 $\left(0.5^{\circ} \sim 2 \%\right.$ $\mathrm{sec}^{2}$ をを加光，目的の速度になつたのち等速度迴転に移 り，一定時間廻転ののち急激汇停止して後眼振及び後感 覚の持続時間を測定するので, Bárány 法の欠点は可な り是正せられる。これがためこれを数種類の速度の廻転 刺战について湘定し，その結果を図示する cupulometry は，理論的にも興味深〉臨床的にも諸学者によって 検討されつかある. しかるにろらに対しこの種の cupulometry を赛施した業積は内外交献沉見当たらない。 よつて私は今回この法を特殊噮境下にある多数のろう者 に実施したのでその倹查成績をこ〉に報告する。本研究 にあつては被検者がうう者であるため主観的な迴鞋感觉 を正しく表示させることは甚しく困難であるので，客観 的に测定の可能な後眼振についてのみ研究を行つた。

\section{II. 検査対象と方法}

1. 被検 者

被梌者は東京教育大学教育学部附属万学校の生徒児 童 214 名中より，全身及び局所の諸検查，並びに家族か らの問匙によつて，比輍的失官原因及び失官年令の判然 とした先天ろら及び後天ろら各50名を撰儿た．すなわ ら先天万らは同胞に 2 人以上のろうのある直接あるいは 間接遗伝と考兄られるすの，両親が血族結婚であるる の, 又は他の身体的な欠晔，なかんつく先天的異常（青 色䑶膜, 先天性股関節脱白，弱視，先天性耳渾孔等）を 伴つているものなどで鼓膜に異常を認めず，生後音刺战
に反応を示さなかつたるのを抽出し，後天ろうは生後音 刺戟に対しかつては明らが反応を示したが；聴力をそ ら失するに足ると思われる程度の重篤な疾患を経過した のら，聴力を失つたものを撰出した．第 1 表は失官原因 別にみた被検者一覧表であり，この失官原因はわれわれ がかつて全国万弓学校在学生徒約 1 万人について行つた 失官原因の統計的観察 ${ }^{36)}$ に持ける成績とよく一致して いる.

第1表 被检者一覽表
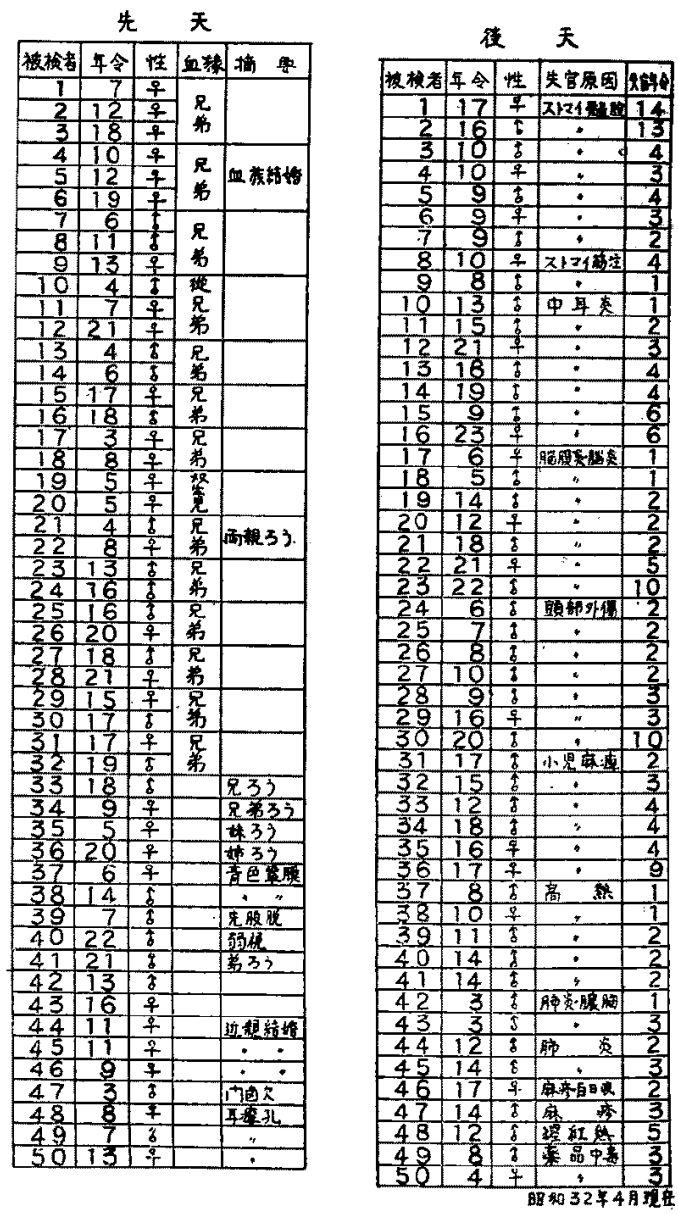

\section{2. 㭘查場所}

檢查の場所は東京教育大学国府台分校生理研究室内に 設㣁された防音室.

3. 桧查期間

検查の期間は昭和 31 年 5 月より 33 年 3 月まで.

4. 刺战方法 
Steinhàusen 23),の実験による Hecht の Cupula の歪 みから理桷的に類推しても, 叉具体的には前項に揭げた ような䧽々な理由から精密な検索には Bárány 法は不 適当であること，またこの不合理珄を改善した緩徐刺㦸 に上る闎值下加速迴転刺战法がより優れた前庭平衡機能 検查法であることは充分肯づけることであるが，闖值下 の加速度迴転を正確に行うことは非常に困難なことであ る、このために迴転萃置には精密な工夫が施こされてい、 る. 即占 Tönnies chair ${ }^{24)}$ あるいは Egmond 25) の䢙

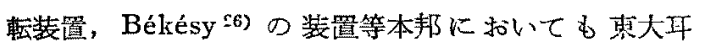

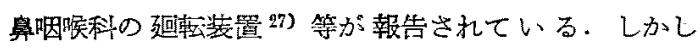
Arslan 28)はこのような装置のない場合, 手勘でも毎秒 $0.5^{\circ} \sim 2^{\circ}$ の初速加ら徐々儿加速延転を始めて，180\% $/ \mathrm{sec}$ になつたならば2〜3 分間等速廻転して後, 急激に停止 させて後眼振をみればよいと述べているが，私の場合る Johnes-Bárány の趣転椅子を用いて 手動式で実影を行 つた，手動式では当然呬転さらを生ずることが考えられ るが第1四に示すような刺战方法で充分熟練すれば迴転 むらが後腿振に影響することなく所期の目的坴達しうる ことを知つた. Buy 29), Fischer 20), Tönnies 24), Ars-

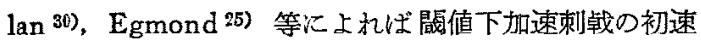
は $0.5^{\circ} \sim 2^{\circ} / \mathrm{sec}^{2}$ であるとされている. 文等速度迴転の

第1图刺戟 様式

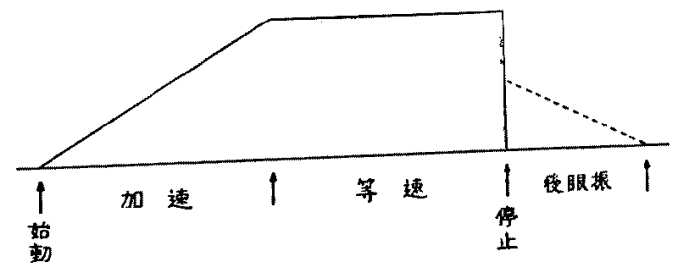

速度はまちもちで Fischer ${ }^{20)}$, Arslan ${ }^{30)}$ は $180^{\circ} / \mathrm{sec}$, Lung ${ }^{20)}$ は $20^{\circ}, 40^{\circ}, 60^{\circ} / \mathrm{sec}$, Jonkees ${ }^{32)}$ は2.5, $4^{\circ}$, $6^{\circ}, 9^{\circ}, 18^{\circ}$ 等に打いてそれ艺れ実験を行つているが， Aschan ${ }^{33)}$ 等の cupulometry においては $60^{\circ} / \mathrm{sec}$ が 最も強い刺战になつている．この等速度迴転を急激にと めて後眼振と後感覚とを計測するのであるが，このよう な刺战方法をとれば迴転当初の角加速に上る眼振（迴転 初期刺钱）によつて後眼振が影㸷されないとしている。 以上のことから展值下刺钱角加速度を的 $0.3 \% / \mathrm{sec}^{2}$ とす るために椅子゙の下に記してある角度と秒時計とを誈み合 せながら60秒，120秒，180秒間加速したあとそれでれ 最終速度を $18 \% / \mathrm{sec}, 36 \% \mathrm{sec}, 60 \% / \mathrm{sec}$ とし，この 3 種 の刺战角速度を 1 分間等速廷転を続けた後急激に停止し
て後腿振を測定した。この際をれ艺れの迴転刺戱の間で は2分間以上の休止をとり，まず左迴転次右迉転刺钱 を行つたが两者の間には後眼振消失後 5 分以上の休止時 問を执いた。かく如くしてまず正常聴力者 10 名につ いて各通転刺㦸に上つて起る後眼振を Barzel 氏腿鏡を 装用せしめて計測したが，その成績は第 2 表に示す 即

第 2 表 正常者の Cupulometry に上る 眼振持繶封間 (10名)

\begin{tabular}{|c|c|c|c|}
\hline 迥䡮速度 & $18^{\circ} / \mathrm{sec}$ & $36 / \mathrm{sec}$ & $60 / \mathrm{sec}$ \\
\hline $\max$ & 20 & 28 & 40 \\
\hline $\min$ & 9 & 22 & 22 \\
\hline 平 & 17 & 25 & $35 \mathrm{sec}$ \\
\hline
\end{tabular}

ら迴転速度が大となるにつれて眼振の持続特間が增す

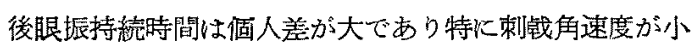
である程その頃同が強いが，Buys 299，Fischer 20) の報 告に上れば，この場合でも Bárány 法上りは眼振分布 の㹡がりは狭いと述へている. 又同時に記録した眼振図 の一部を第 2 図に示すが，いずれの加速度に批いても手 動式であるために迴転さらが起り加速及び等速のいずれ の場合にも僅が眼振図の上で上向きあるいは下向きの 振幅の小さい動きをみるが，手動式の迴転椅子でも注意 梁く延転剂战を行えばほミ゙初期の目的を果すものである

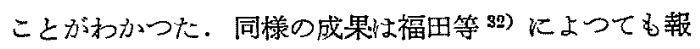
告されている，

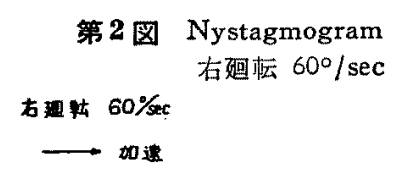

tions $/ 5 \sec$

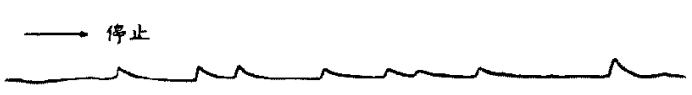

$11-131$ 
Aschan かi正常者 320 例について得た後眼振持緢持间 の平均值，本実歌で正常者 10 名の平均値，さらに手 動式での三沢 ${ }^{231}$ ，朴沢 34) の報告及び電動式での小倉 ${ }^{35}$ の成續を同一グラフ.上に 記載したものが第了図である が，電動式と手動式とでは刺㦸の与方方に多少の違いは あつても結果に扣いては著しい差異は認められない，即 ら手動式迎転筒子による閶値下加速度迴転刺㦸法でも所 期の目的は達し得られるといら確信を得たのである.

第3国本实㗼と他 Cupulogram との比較

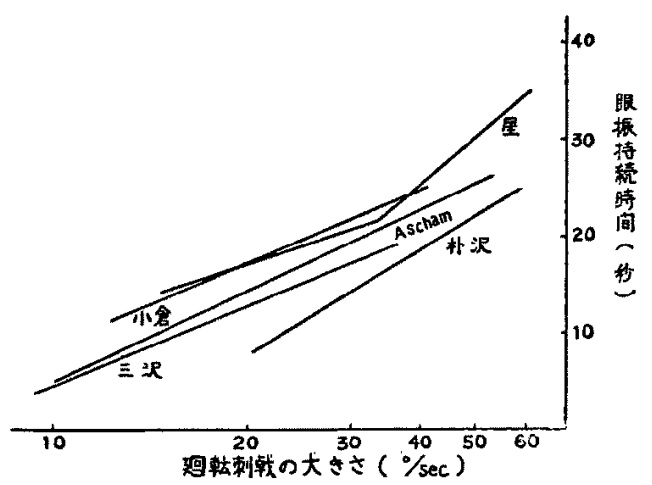

III. 検查成精

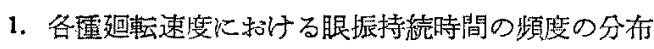

(1) Bárány 法によるもの(自由撰択による 被梌者群の価値検討)

cupulometry の刘称となつた被検者は，ろら学校在 学生 214 名中より自由貲択により 100 名を撰んだが，て の前庭機能が撰抜母体のそれを代表し得ない特殊なるの であつてはいけないそこで全員 (214名428 㑡)につ いて Bárány 法を行い後腿振発現の模様を調べた，そ

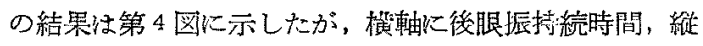

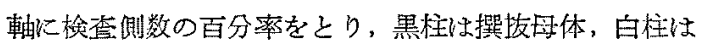
cupulometry 被検者を示要 横軸に特ける“0”眼 振発現が全くなかつたもの，“1〜 5”隹腿振持続持間が

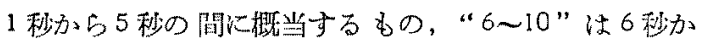
ら10秒間眼か゚持綍したものであり，以下同様にして 示されている。これによる上撰发母体となつた効称群及 び撰拔された被检者群では，眼振陰性の百分率はそれぞ れ $25.7 \%$ 及び $25.0 \%$ であり，眼振陽性のものについ は撰抜母体では“16〜20”秒 19.2\%，撰烄群では“21 〜25”一秒 $17.5 \%$ が先れを゙れ分布の最高を占め, これ
を山として性上正规分和を示している，即ち両群の分布 状態には顕著な差異が認められず，従つて本実験に貲ば れた被検者が一般万らに比較して特異な傾向を持つるの ではないことが知られた。

第4图 Bárány 法による哏振持続時間の頻度分布

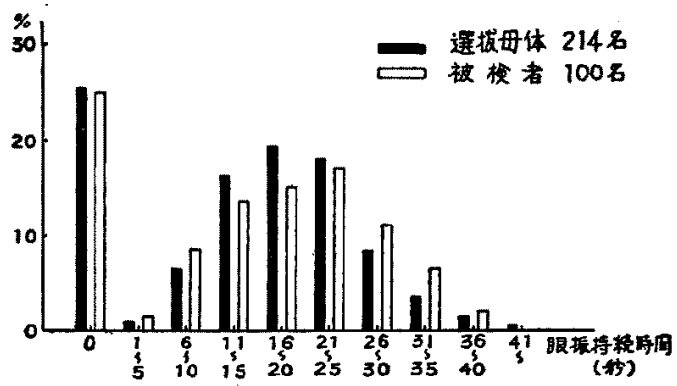

（2）䈅值下加速度建転刺㦸によるもの

自由に撰択された被険者 100 名 200 側に対し闒值下䢙

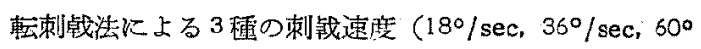
/sec）に标るそれぞれの眼脤特綕時間の頻度分布を第 5 図に示した。图中下段は $18 \%$ secについての分布であ り，中段は $36 \%$ sec，上段は $60 \%$ sec にいての分布状

第 5 図閏值下刺戟洗による眼振発現頻度分布
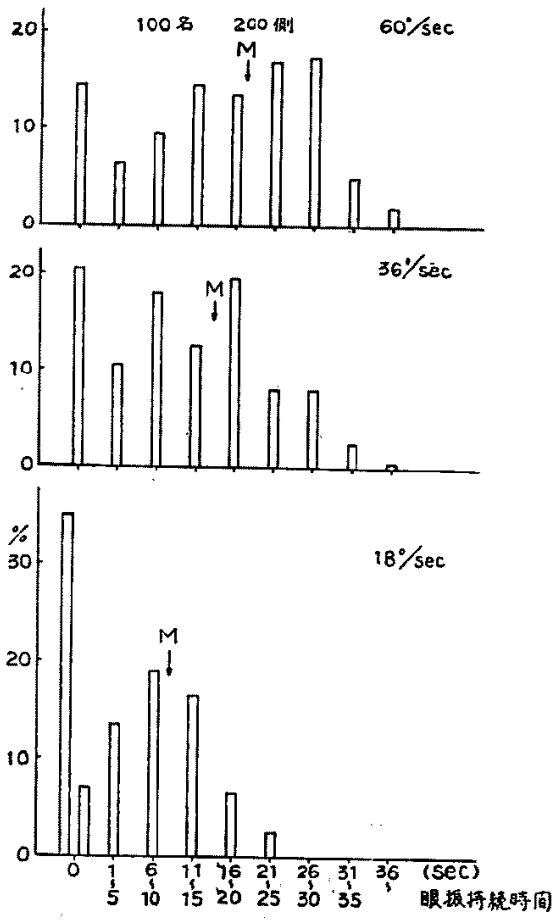
涗である.いずれる横軸には眼振持続時間を区分し，縦 軸性被検側数の百分率をあら方している. 刺㦸速度が $18 \% / \mathrm{sec}$ か⿰氵 $36 \%$ sec, $60 \% / \mathrm{sec}$ と增与に従つて眼振の 陰性率は $43.0 \%, 22.5 \%, 15.5 \%$ と澌減し，逆作脤陽 性率仕 $57.0 \% ， 77.5 \% ， 84.5 \%$ 之潎增を示している。眼 振陽性率の最高は $180 / \mathrm{sec}$ では “6〜10”秒厄 $19.0 \%$ ， $36 \%$ sec では "16 20" 秒に 19.5\%, 60\%/sec では “26 〜30”秒汇 17.5\%であり，これより“1〜5”秒から “36〜”秒までの間で図の上うな分标状態を示してい る。図中矢印は腿振陽性率分有の平均点を示すむのであ 尚。

2. 先天・後天別の腿振持続時間の頻度分布

第6 四及び第7図はそれぞれ先天ろら及び後天ろら各

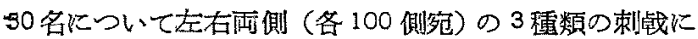

第6 図 先天るらの閜值下刺戟法による 眼振発琴頻度
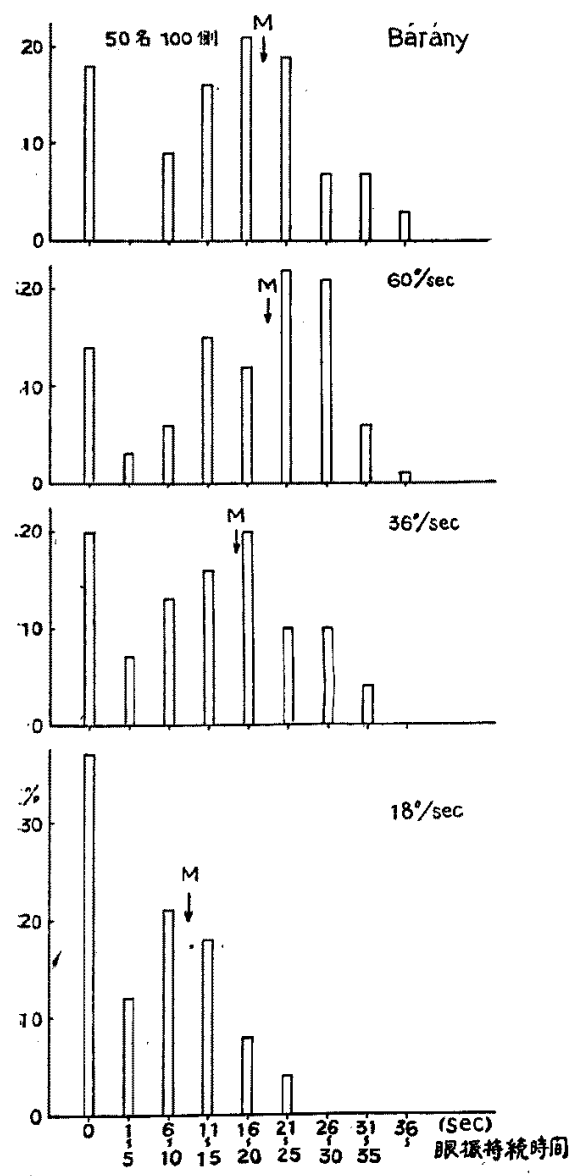

第 7 图 後天る5の閔值下刺戟法に上る 眼振発現崸度
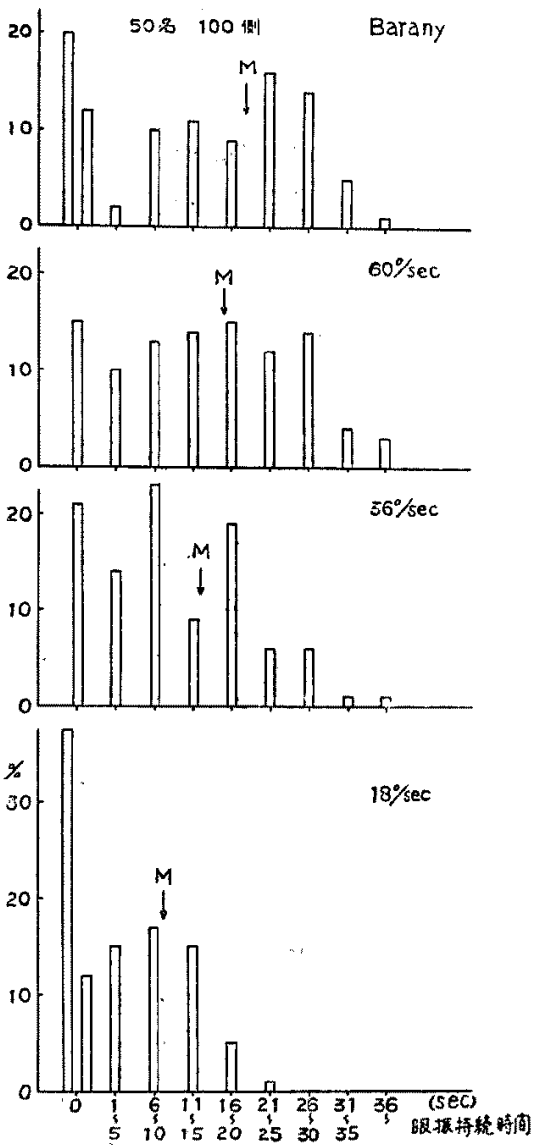

対する眼振持綕時間の頻度分布図である．最上段には比 較のために同一被検者に対して行つた Bárány 法での 分布図を揭げた，先天については眼振陰性率は $18 \%$ $\mathrm{sec}, 36 \% \mathrm{sec}, 60 \% / \mathrm{sec}$ で $37.0 \%, 20.0 \%, 14.0 \%$ 之順次 減少し，後天でも同様 $47.0 \%, 21.0 \%, 15.0 \%$ 之減じ，

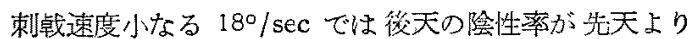
10\%上回るが，36\% $/ \mathrm{sec} て ゙ 2$ 先天・後天共汇同率であ る. Bárány 法で㑡振陰性率徒先天 $18.0 \%$ ，後天 32.0 \%で後天の力が滛か㒀く，から先天ては Bárány 法 での陰性率娆天の $36 \% / \mathrm{sec}$ の場合之汪心同率であり， 後天の $36 \% / \mathrm{sec}$ 上近似の值を示している.

眼振陽性率汇ついても先天と後天とでは眼振持綕時間 の頻度分布に差異が見られ，後天では舆型的な正規分布 を示さない，即ち先天では 18\% / sec で“6〜10”秒 20.0 $\%, 36 \%$ sec で“16 20”秒 $20.0 \%, 60 \% / \mathrm{sec}$ で “21〜 
25 ”秒 $22.0 \%$ ，Bárány 法で “21〜25” 秒飞 17.5\%を 頁上としてほ上゙正規な分布を示している。これに反し後 天ではこの上うな傾向が極めて尠い，又後天は眼振持続 時間の短いものが多く，先天に和ける“1〜5”秒での 眼振持綄の百分率が $18 \% / \mathrm{sec}, 36 \% / \mathrm{sec} ， 60 \% / \mathrm{sec}$ でそれ ぞれ $12.0 \% ， 7.0 \% ， 3.0 \%$ と浼減するのに対し，後天で は $15.0 \%, 14.0 \%, 10.0 \%$ 之左程著明な減少は認められ ない，特飞德天の $60^{\circ} / \mathrm{sec}$ に括ける眼振持続時間の頻 度分析性“ $1 \sim 5 ”$ 秒上り“26〜30”移の間で 10.0\%

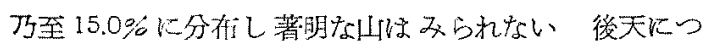
いての Bárány 法では先天の場合と同樣“21〜25”秒 16.0\%を頂上にしてほら゙正規分布を示し，さらに“1 5 ”秒が櫵かに $2.0 \%$ 见過ぎない等, 閶值下刺榦法の民

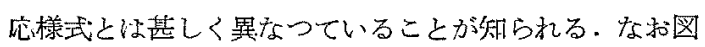
中矢印は眼振陽性率の平均点を示す.

\section{IV 絵括之考按}

1. 各種盂転速度に括ける眼振持続時間の頻度分布 撰抜母体及び被検者の Bárány 法によるそれそれの 眼振持続時間の頻度分存认洞じ㑯向が見られるから被 検者群は撰拔母体を代表し得るものである。

第 4 図化示守如く被検者群の眼振陰性の頻度は 25.0 $\%$ であるが，こ礼を他の文献に比較してみると吉村 ${ }^{17}$ は22\%，二容らは26\%，Bezold》 は28.8\% と報告し て和り、従来の報告とほぶ一致している. 又眼振陽性の むのについての持続時間の分布をみる上，被検者群では “21〜25”秒間で 17.0\%が最高で“1〜5”秒から“41 〜45”秒をでの間で正規分布を示して和り，これる又 二裳，吉村等の報告と上く一致している. 即も本実駼被 検者群の眼振発現の模様は従来報告されたるのと異なら ない.

次に 3 程類の閾値下迴転刺㦸法に上る眼振持続時間の 頻度分布（第 5 図）では迴転速度か゚大になるに従つて眼 振陰性のものが目立つて減少し，18\% $18 \mathrm{sec，36 \%} \mathrm{sec}$ 間で その傾问が著明であり，36\% $/ \mathrm{sec}, 60 \% / \mathrm{sec}$ 間にはそれ程 の差は諰められない，即も $180 / \mathrm{sec} て ゙$ 眼振陰性のもの が $43.0 \%$ あるが, $36 \% / \mathrm{sec}$ でとと半数の $22.5 \%$ に減 じ,ざにに $60 \% / \mathrm{sec} て ゙$ 15.5\%に減ずる. Bárány 法 での㓌性率山 $25.0 \%$ で $36 \%$ sec 及び $60 \% / \mathrm{sec}$ の場合上 りも発現頻度が低い（陰性率は高い)，つまり cupulometry の方が発現頻度が高いことが知られる。

眼振発現陽性のものについては刺战が大になるに従つ て眼振の持続時間も增し，その頻度分布は右方に移行与

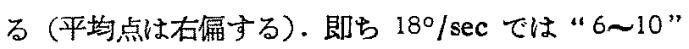

秒 19.0\%を分布の頂として“1〜5”秒より“21〜25” 秒むでの間に分布し，36\%/sec で “16〜20”秒19.5 \%をとの頂として“1〜5”杪より“36〜”秒までの間 に分布し，600/sec では“26〜30”秒17.5\%を分布の 山として“1〜5”秒上り“36〜”秒委での間に分布し

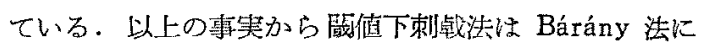
比輍して腿振の発現率が高く, $36 \% / \mathrm{sec} て ゙ 5 \%, 60 \% / \mathrm{sec}$ では10\%增加している. 㕛 Bárány 法では “1〜5” 秒，亦なわ極く短時間哏振の認められるものか゚僅か 1.5\%であるのに反し，䦨值下刺戟法では $18 \% / \mathrm{sec}, 36 \%$

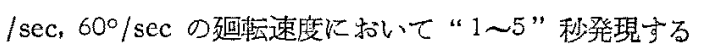
ものがそれ艺れ $11.5 \%$ ，9.5\%，6.5\%に認められている。 たざしその腿振の様式が定型的に急速相之援徐相が判然 としないような小振腷のものである場合が多いのである が、これがどのような mechanismに上るすのであるか. は更に検傠を加党る必要吕あるう。

\section{2. 先天・後天別眼振持続時間の頻度分布}

眼振持綕時間の頻度分析図を先・後天別に作ると第6。 図及び第7図のようになる。即ち眼振除性率は先天では $18 \% / \mathrm{sec}, 36 \% / \mathrm{sec}, 60 \% / \mathrm{sec}$ の順に隇少し，後天でる同 様の減少を示すが減少は先天上り後天の方が著明であ. る. 先天及び 後天の㓌性率を比畭すると $18 \%$ sec では. 先天 $37.0 \%$ に対して後天 $47.0 \%$ で後天が 10\%上回つて いるが，36\%/sec 及び $60 \% / \mathrm{sec} て ゙ は$ 先・後天間に差が ない. しかるに Bárány 法での㓌性率は先天では 18.0 \%であるのに対し後天では $32.0 \%$ と遥加亮率を示し ている.

眼掁陽性のわの土頑度分布については, 先天ではどの 刺戟速度に上る場合でも，ほ亡゙正規分布を示し，分布の 最高は刺載速度か゚大になるにつれて右に偏し, 後天でば この傾问が勘く，刺战速度が增すに従つて分布も右に腐 してはいるが，な和眼振持俧時間の短い左側寄りにも相”

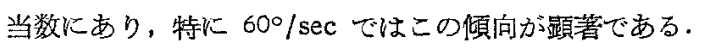
即占“1〜5”秒から“26〜30”秒むでの間で 10 乃至 15\%に達している。眼振陽性率の頻度分布の平均点歹 文右に偏するが，この傾向も後天上り先天において著明 であり，3種頪の迴転刺戟でそれぞれの平均点は先天が. 後天より約 1 目盛右にずれている。このことは後天にお ける眼振がたと六陽性であつても，その持綕時間が短い ということを意味している．即ろ機能低下は後天の方が 著明であると云壳よう.

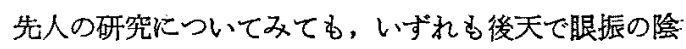
性率高く, Bezold 1) は先天と後天の陰性率を 23.8\% 䴔 
180\%とし，吉村 ${ }^{17}$ は は $19.5 \%$ 対 $34.5 \%$ としている. 即 ら本実験に括る Bárány 法の場合之同様の成績を挙 げている. 従つて平衡機能廃絶者が先天に比べて後天ね 遥かに多いと断定しているが，閔值下刺㦸法によると先 天と後天とでは眼振の持続時間には差を認めるが発現率 には大差がなく，このことから先天よりる後天に機能の 低下はあるか゚，廃絶者がより多いとは云い得ないことに なる。

これを要するに閶值下刺戟法は Bárány 法に比較し てより適切な㯨㦸方法であり，この方法を用いた場合 Bárány 法で眼振の発現をみなかつたものでも闌値下刺 战法で陽性に転ずるものがあり，この傾向は特に後天に 顕著であつた．即ち後天において Bárány 法で陰性で あつたるの今中 $20 \%$ 蒻が陽性に転じている．第 3 表を みると第6図及び第7四に括ると同様刺战速度が大と なるに徒つて眼振の発現頻度は高くなつているが，18\% :sec, $36 \% / \mathrm{sec}, 60 \% / \mathrm{sec}$ の 種の刺战に対してどのよう に反応するものであるかを先天及び 後天別に示してい

第 3 表 先天・後天別三種類の閵值下刺戟に 対する反応頻度

\begin{tabular}{|c|c|c|}
\hline & 先 天 & 唛 天 \\
\hline $18^{\circ} \cdot 36^{\circ} \cdot 60^{\circ}$ (反応 & 62 & 53 \\
\hline $36^{\circ} \cdot 60^{\circ}$ のみに反応 & 18 & 25 \\
\hline $60^{\circ}$ のみ心反应 & 6 & 7 \\
\hline 反底等 & 14 & $14 \%$ \\
\hline
\end{tabular}

る. 即ら 3 種類の刺戱全部に対して眼振のみられたもの

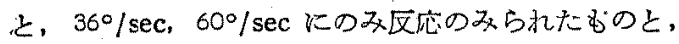
$60 \% / \mathrm{sec}$ のみに眼振のあらおれたるの及び反応のないる の土4群に分けたが3刺战の全部に対して反応を示した めのは先天 62\%，後天 $53 \%$ で先天に多く，36\% と $60 \% \mathrm{sec}$ に反応のあるbのは先天 $18 \%$ に対し後天 $25 \%$ で後天に多く，60\%/ のは先・徭天それそれ6\%，7\%でほ心゙同数となつてい る.これは刺㦸速度が大となるにつれて眼振の発現頻度 む增すが，この傾问は特に $36 \% / \mathrm{sec}$ までに顕著であつ て $60 \% \mathrm{sec} て ゙ は$ 僅かな增加をみるに過ぎず，このこと は特に後天に著明である。

第 4 表は本害験比いて得られた Cupulogram が正 常者のそれとどのような関係にあるかを倠察するため に, Aschan 等の報告による正常者 320 例の平均 Cupulogram $^{38)}$ (第 3 図) と比較検討したものである.表中 傾斜度度“大”とあるのは正常者の平均 Cupulogram
の傾斜と比較して，被㭘者 Cupulogram の傾斜が急 で刺钱速度が大となるにつれて眼脤発現時間の增加率 が正常者のそれよりる大であることを瑟制する。“等” は正常者の曲總に平行であるか，あるいは全く一致する ものであり，“小”は正常者のそれに比して做斜角度の 小さいことを示す：これによると先天・後天のいずれを 闍方す傾䣄角度が正常と等しいものが最多数を占め（先 天 $46 \%$ ，後天 $34 \%$ ，これ次次いで先天では傾斜角度の

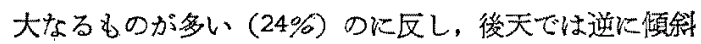
角度の小なるもの小方が多い(26\%). 即ちたと立機能 の低下はあつても先・後天とも正常者と同様の反奻様式 を示するのが最も多く，次多いのは先天では刺战速度 が大になるに従つて腿振持続時間の增加率が正觉渚より 上迴るむのであり，後天では逆に下㻁るるのである．即 ら後天では眼振持綕時間の增減が刺战速度のそれに並行 しないものが多いことを意昧している。

第 4表 ろちと正常者との Cupulogram の比較

\begin{tabular}{|c||c|c|}
\hline 倾斜角度 & 先天 & 啳 天 \\
\hline 大 & 24 & 11 \\
\hline 等 & 46 & 34 \\
\hline 小 & 10 & $26 \%$ \\
\hline
\end{tabular}

同一被検者比打る左右廷転の Cupulogram につい ては，雨者が裂声るるの，平行するもの及び一致する あのがそれそれ 20\%〜30\%に双られたが，このことは 先天・後天を問わず，反応形成に個人差はあつても同一 個人に和ける左右羑はないと云らことを意味する。

又先・後天とも刺钱速度が增すに従つて眼振持緢時間

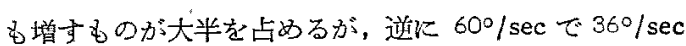
より減少するものがそれぞれ 10\%弱に認められる。し かし刺战速度が大になるに従つて浲進的に眼振時間が減 少する例は殆んどみられなかつた。

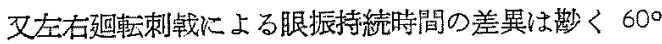
/ sec に批いてのみ左右間に10秒以上の差のあるものは 先天になく，後天に3例を認めたに過ぎない，

3. Bárány 法㓌性で闌值下刺战法陽性の6の 対方梌訶

Bárány 法に衿いて廷転刺战に反应を示さない症例て 閶值下刺㦸に眼振の認められたものが15 例あつた， そ の内訳は第 5 表の如く先天 4 例 5 側, 後天 11 例 19 側で 後天万らに著しく多い，両側迴転に反応陽性となるも のは先天 1 名に対して後天 8 名で，後天に多い，即ら 
第 5 表 Bárány 法陰性, 閣値下刺戥法 陽性頻度

\begin{tabular}{|c||c|c|}
\hline & 先 天 & 後 天 \\
\hline 画側上を反応 & 1 & 8 \\
\hline 偏側の4反応 & 3 & $3 \alpha$ \\
\hline
\end{tabular}

Bárány 法が陰性にもかつ和らず間値下刺战法で陽性と なるもの後天に多いことが知られた。ささらに第6表に 示すよう各刺戟速度に対する反応の状態をみると先天で は $36 \% \mathrm{sec} ， 60 \% / \mathrm{sec}$ にのみ反応するもの3 側, $60 \% / \mathrm{sec}$ Кのみ反沁するもの 2 側, 後天では 3 程類のすべてに 反応するすの 3 側， $36 \% \mathrm{sec}, 60 \% / \mathrm{sec}$ 反反応するもの 14 侧, $60 \% / \mathrm{sec}$ のみに反応を示するの 2 側であつて， $36 \% / \mathrm{sec}, 60 \% / \mathrm{sec}$ の刺幟速度で反応するものが急增する ことがらかが党る。

第 6 表 Bárány 法陰性, 閾值下刺戟法 陽性例の反応頻度

\begin{tabular}{|c|c|c|}
\hline & 先 天 & 後天 \\
\hline $18^{\circ} \cdot 36^{\circ} \cdot 60^{\circ}$ に反応 & 0 & 3 \\
\hline $36^{\circ} 60^{\circ}$ の21二反応 & 3 & 14 \\
\hline $60^{\circ}$ のみに反応 & 2 & 2 \\
\hline 竍 & 5 & 19 侧 \\
\hline
\end{tabular}

閶値下刺战では眼振陰性で Bárány 法によつて眼振 の発現をみた例は後天に 1 例 1 側のみであり，Bárány 陰性で閶值下刺棹で陽性にでるもの先天・後天とる計

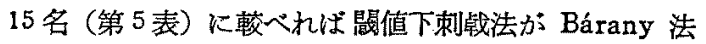
に優ることがわかる。

4. 閾値下刺幟法による眼振持続時間と聴力との 関係

先天・後天各 50 名の被険者について，60\%/ sec 迴転 刺戟によつて発現した眼振持続時間と聴力損失との相 関々係を第 7 表江示した。迴転速度は 3 種の中 $60 \%$ sec

第 7 表 眼振持続時間と平均聴損との関保

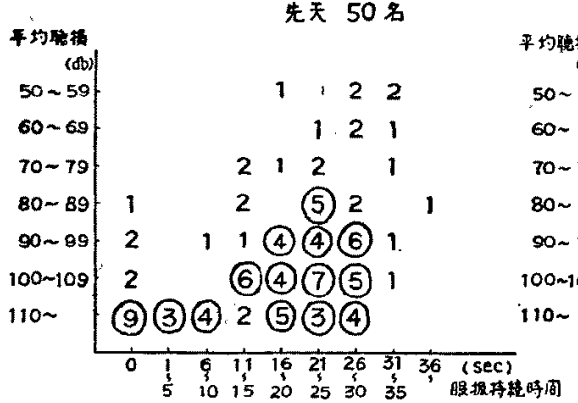

に执いて眼振の発現率が最高であるので，この刺僦速度 を撰んだ。縦軸は $500 ， 1000 ， 2000 \mathrm{cps}$ に和ける聴力損 失の平均値であつて，冬居波数ともAudiometer の最大 出力 $125 \mathrm{db}$ でる聴取不能の場合は聴力損失 “110 ” db の列に含めた，横軸は腿振持続時間である．表中頻度 は 以上を丸印で囲んだ. 左廷転剌战の眼振には右耳の聴力 損失を，右建転刺㦸の眼振には左耳聴力をそれそれ対応 させてある，先天・後天ともに聴力損失 “50 59.” db

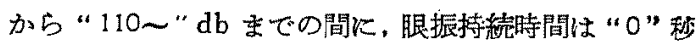
から“36〜”秒までが分布している. 先天では聴力損失 が大なる場合にも眼振持続時間が長いものが相当数住認 められ，相関々係はあまり著明ではないが後天では先天 に比してょり著明な相関があるように見受けられる。そ の理由として次のことが考えられる，即ち個体発生は系 統発生を繰り返すから，先天に和いては胎生期の一時期 に侵㢣が及んだとしてもその時には前庭半規管の方が蝸 牛に比して上り高度の発育を遂げていた筈である. 個か の例について侵繁の時期を異にすればその時迄の而者の 発育状態に差肪あるから生後の両者の残存機能の差異の 上に规則性を持たないのは当然である，後天においては 両者の発育は一応完成したところへ外来の侵篦が及んた ものであるから，障害の程度が両者で同率であるべき可 能性は強い管である。しかし先天・後天のいづれにおい ても聴力損失はろうの程度に高度なむのであるのに反 し，廻転性眼振は管から正常者之同程度のものまであっ て，聴覚と平衡機能とは並行しないものがあることが分 る. 即ち聴覚機能の方がより高度に障害されているいの

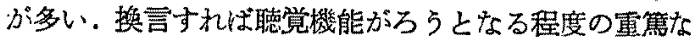
侵要を受けているにもかつからずな执前庭平衡機能が 残存しているものがあること, 即ち解剖学的に同一の迷 路款によつて被覆保護されているにもかわわらず蝸牛之 前庭半視管ではその機能の残存の程度に差異が認められ

る.このことより前庭半 規管は蝸牛に比し病的侵 聚に対し抵抗性が高く， 沿淹傾向も強いことが 考吝られるが;これは Mygind ${ }^{37)}$ のろ5の部 見例の報告でも実証さ机 ている.

5. 先天・後天別 Cupulogram の相違飞 ut 
(1) 先天万5の Cupulogram

第8図にはろう兄弟の Cupulogram を同一図中に正 常者の平均 Cupulogram(Aschan)と〉むに記した。即 ち50名中 32 名は兄弟あるいは従兄弟であつて，その内 訳は前篇之同様で，図の番号は名庭例每に Audiogram のそ机と対応させ，かつ Audiogram と線程を同じ くするものは同一被検者であることる意味する，即ち Cupulogram の実楾，点線等はこれと同一番号の Audiogram の契䠌，点線等とそれぞれ同一被梌者のむの を表わしている。

双生児（第8図8）に打いては眼振発現の模漛恃相似 しておう，共に $18 \% / \mathrm{sec} て ゙$ 発現なく $36 \% / \mathrm{sec}$ 々 $60 \%$ sec で発現をみている. 前記 Audiogram についても 同様のことがみられる。な技本例は一卵性双生児で前庭 機能でも㯖覚でも同胞閏で類似の低下を示すことは與味 梁い。

第 8 图 万ら兄弟の Cupulogram

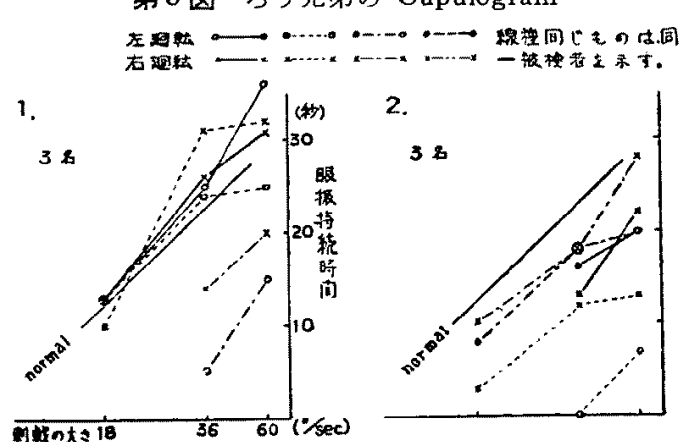

3.

$3 \%$

उ名

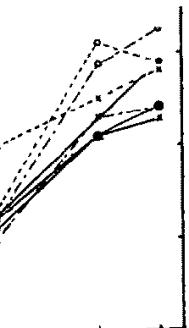

5.

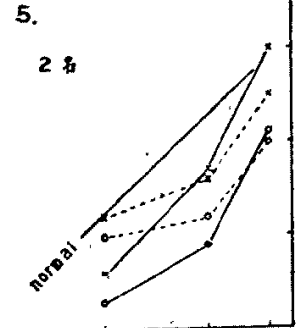

7.

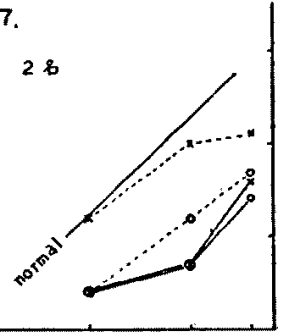

9.

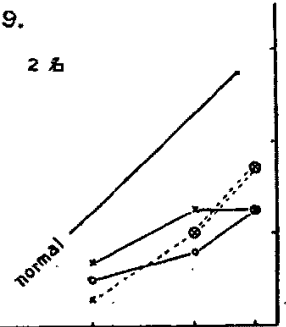

11.

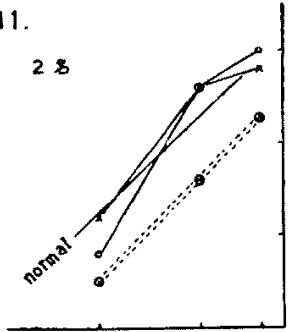

13.

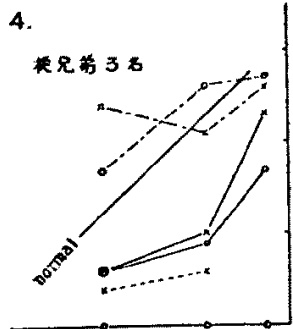

6.

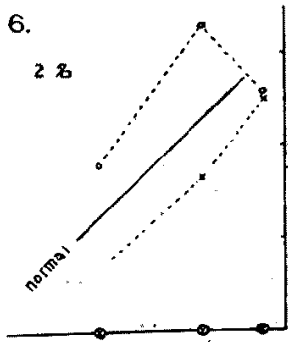

8.

双生义

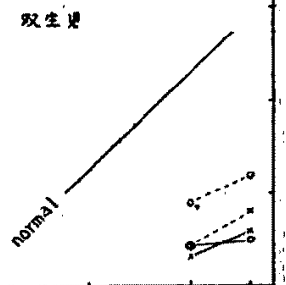

10.

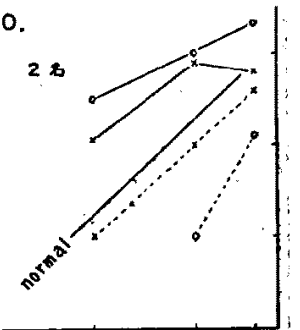

12

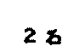

$2 \%$
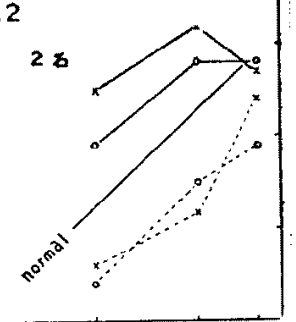

14.

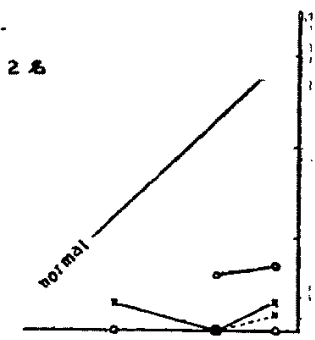

兄弟同志の Cupulogram のうち第 8 図 3，5，9，11， 13，14の6 症例では大体同型の反応を示し，1，2，6，7， 10，1206 症例では眼振の発現に著明な差異が羿められ る. 即ち兄弟同志で応様式が類似するむのと，相逵す るものとがそれぞれ同数汇認めら机，先天ちらの兄弟で も必ずし死類似の前庭機能の但下を示すとは限らない 9 に括いては両親ともにろうで，遗伝的要素が濃厚で あると考觉られるが，Cupulogram も類似し聴力像も 㕛近似している．母親同志が姉娃である従兄弟3名の. 
Cupulogram (4) 飞差異が孖られ聴力像にも 類似性が sw.

(2) 後天万弓の Cupulogram

第9 図は後天万弓50名の中から失官原因として頻度 の高いStreptomycin，中耳炎；脳膜炎，脳炎，頭部外

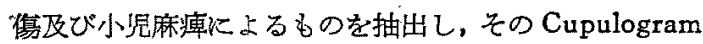
芝失官原因別に示したもので西り，前篇第 13 図の番号 及び線種で示するのと同じ番号及び線種で表わするのは 同一被検者のそれである。即ち1より3までは Strept. romycin に上るろうで1,2 は結移性脳膜炎のため鲔腔 内に注入した 7 例，3は肺結核のため筋注を行つた 2 例 沉つての Cupulogram である. いずれについてる機 能低下が認められるが，筋注の場合は噵腔内注入に比較 して軽度である。

第9図 4，5 には中耳炎による失官 7名を示した。いず

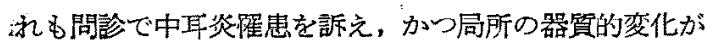

第9図失官原因別にみた後天るらの Cupulogram
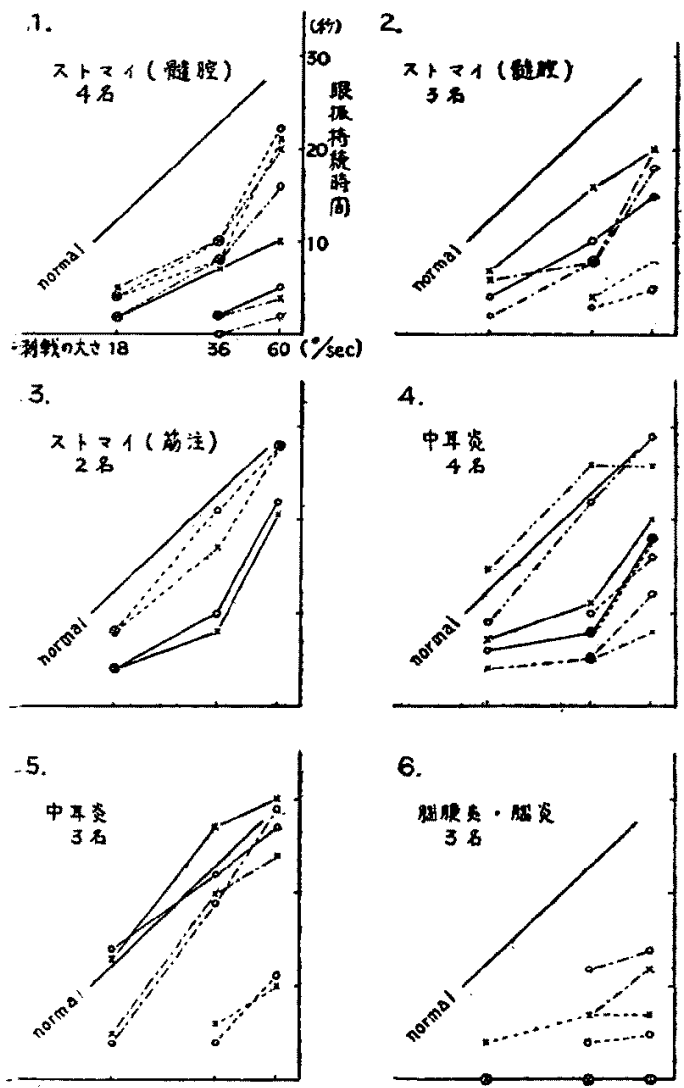
6.

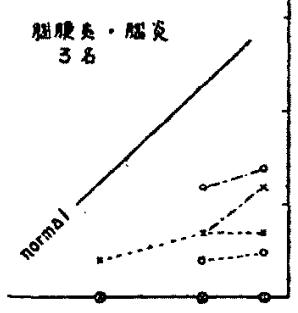

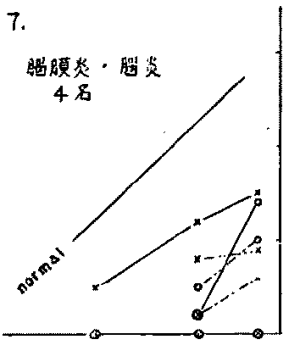
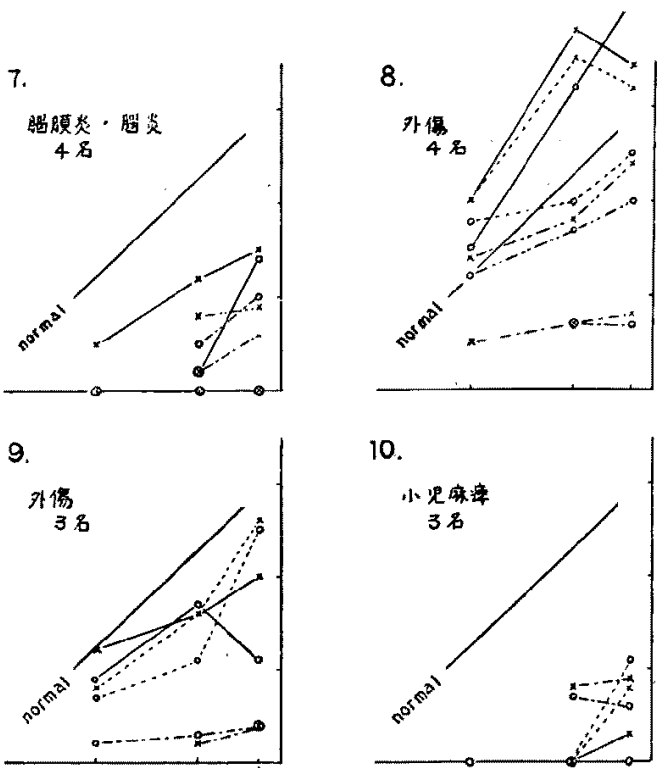

11.

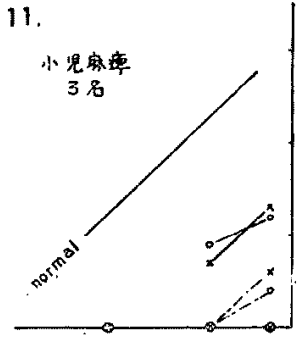

著明なむのである・眼振の発現度は正常值に近いるのか ら極めて僅かなるのまである，従つて中耳炎性の内耳侵 酸は程度も部位む多種多様であつて前庭機能低下の度も まちまちであると解釈される。

6, 7 は脸膜炎及び脳炎による失官 7 例の Cupulogram であるが，全例とも機能低下著しく，脳膜あるいは脳実

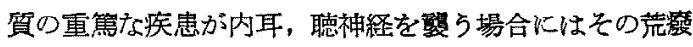
は高度であることが推察される。

8,9 は頭部外傷により聴力を失つた 7 例の Cupulog- ram であるが，眼振発現が正常者上同程度のるのから 高度の㙨能低下を示するのまですりこれも外賃の部位 と程度倍存する結果であると考劣られる。

10，11では小児麻瘦によるもの6例の Cupulogram である. 全例に高度の機能低下が認められるが，小児麻 痺 Virus が特に神経に親和性が強いるのであり，これ が内耳, 聴神経を犯寸場合その障書の激しさを物語つて 
いるものと思ら。

\section{V. 結 論}

ろう 100 例（先天 50, 後天 50) について間值下迴転 刺皒法による平衡機能検查を行い，その成續と同時に行 つた Bárány 法による検查成續及び Audiogram と比 較検討し次のような結諭を得た。

1. Bárány 法に比蓉して cupulometry では眼振陽 性率が高く，赖战速度が大となるに従つて眼振晹性率は 增し，又腿振持結時間も長くなる。同一被検者のCupulogram は左右迴転でその発現样式に大差を認めない.

2. 先天及び後天の Cupulogram を比較すると眼振陽 性率はほら相等しく，先天が後天より遙が高率を示す Bárámy 法とは甚しく趣きを異にしている，眼振陽性 者については眼振持続時間の長いるのは後天より先天に 多く，眼振持続時間は零から正常值をで広䠉囲に分布 し，後天では眼振持続時間が極く短い子のが比较的に多 い. 即ら先天・後天ともに譏能廃絶者は同程度に見られ るが, 残存機能が低下しているすのは先天上り後天に多 いことを知つた。

3. 聴力低下の程度と平衡機能低下の程度とが一致し ているものは後天に多く、聴力低下の程度に斡べて平衡 機能がな怙残存するすのは先天に多い，かつ㮦覚がう5 の程度にまで犯されていながら前庭機能が牫存している ものが相当数みられる、このことは先天・後天で侵繁の 時期を異にすること，前庭半規管と蝸牛とでは病的侵尛 に対する抵抗性が異なること等から説明される。

4. 先天万弓兄矛の Cupulogram については反応様式 を同しくするものと，異にするるのとが相半ばしてお

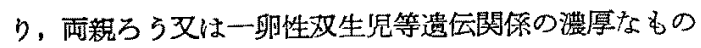
では反応样式が近似し，母親同志が姉林である従见弟同 志の例では反応様式に類同性がみられなかつた。

5. 後天万50失官原因別 Cupulogram に上れば、脑 膜炎，脳炎，小児麻瘏等では機能の低下が高度であり， Streptomycin, 中耳炎, 外傷では機能低下の程度む檑々 で、殊に Streptomycin では筇注よりる鲢腔注入によ るむのフ方が低下の程度が高度であることを知つた。

\section{女 献}

1) Bezold, Fr.: Das Hoervermoegen der Tanbstummen, Bergmann 1896. 2) Brock, W.: Denker u. Kahler sche Hanndbuch, Bd VIII 439 454, 1927. 3) Hasslauer, V.: Z.t.O., 37, 437, 1906. 4) 内目: 日耳鼻，34，525 612，1930. 5) 二宮，曾田，成瀬：

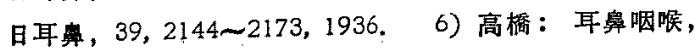

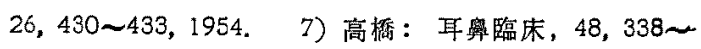
339,1955 ，8）高原：耳鼠全書，Bd I, 1953. 9) 揌力測定法の規準：音響誌，12,1956. 10) Denker: Z.f.O. Bd 36,1900. 11) Kano: Z.f.O.Bd. 141 149, 1936. 12) 加藤：耳奥臨床，22，1954。 13）佐藤： 医事新報, 1711,3〜11,1957，14）Kreidl: Pflüger's Arch. f. d. physiol, Bd 61, 1892.15$)$ Strehl: Pflüger's Arch. f. d. physiol. Bd 61, 1895. Bruck: Pflüger's Arch. f. d. physiol. Bd 59, 1895. 17) 吉村之の他：日耳舆，47，660〜718, 1941 。

Bárány: Monatschr. f. Ohrenheilk. 41, 477 $\sim 526$. 1907. 19) A.A.J. van Egmond et al: The Function of the Vestibular Organ, Basel, New York.

S. Karger 1952. 20) Joseph J. Fischer: TheLabyrinth, Physiology and Function Tests, New' York 1956. 21) C.S. Hallpike et al: Acta Otolaryng. 42, 511 538, 1952. 22) G. Aschan, et al: Acta Oto-laryng. 43, 22 26, 1953.23 ) W. Steinhausen: Arch.f. d. ges. physiol. 217,747 762, 1927. 24) Tönnis J.F.: Z.f. Hals- Nosen u. Ohrenh. 30 . 535, 1932. 25) A.A.J. Vn Egmond. et al: Laryng. Otol. 2, 63 78, 1948. 26) Békésy G.: Arch. Oto-laryng, 42, $511 \sim 538,1952$. 27) 切替他: 医科 機棫染誌, 26, 4〜14, 1956. 28) Arslan, M.: Ann. Oto-laryng. 71, 113 122, 1954, 29) Buys, E.: Monatschr. f. Ohrenheilk. 47,675, 1913. 30) Arslan,. M.: Acta Oto-laryng. Supp, 122, 1956. 31) Jonkees. L.B.W. et al: Acta Otollaryng. 42, 451 459, 1952. 32）福田他：耳鬼咽喉，28，699〜705，1956. 33) 三 沢：耳舅咽喉科展望，1，7〜23,1958。34) 䄭沢：日

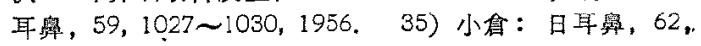
$107 \sim 123,1959.36)$ 荒川, 藤田, 星: 児童心理之精 神就生, 15-2, 41 47, 1954. 37) Mygind: Kurze: Beschreib. d. Schläfebeine Taubstummer. 103 123, 1892.

稿を終るに当り，終始御指尊御鞭撻下さいる した寿原教授，滕田偝師，横浜医大柏户教授に 梁甚なる韵意を表すると〉もに，いるいる御便 宣を与えて下さい来した教育大学附属万う学校 镸萩原浅五郎先先に感謝の意を棒げます。

なお本諭文の要旨は昭和 30 年10月日本音遙 学会及び日耳東京地方会第334回例会に怙い てそれぞれ報告した。

（原稿到着 $=$ 昭和 35.10 .3 日一急載） 